Wright State University

CORE Scholar

Doctor of Nursing Practice Program Projects

Nursing Student Publications

2012

Cardio Pulmonary Resuscitation Decisions in Nursing Home Residents

Melissa S. Bennett

Wright State University - Main Campus

Follow this and additional works at: https://corescholar.libraries.wright.edu/nursing_dnp

Part of the Nursing Commons

Repository Citation

Bennett, M. S. (2012). Cardio Pulmonary Resuscitation Decisions in Nursing Home Residents. . Wright State University, Dayton, $\mathrm{OH}$.

This Doctoral Project is brought to you for free and open access by the Nursing Student Publications at CORE Scholar. It has been accepted for inclusion in Doctor of Nursing Practice Program Projects by an authorized administrator of CORE Scholar. For more information, please contact library-corescholar@wright.edu. 


\title{
Cardio Pulmonary Resuscitation Decisions
}

\author{
in \\ Nursing Home Residents
}

Melissa S Bennett MS, APRN, GCNS, LNHA

Submitted in partial fulfillment for program requirements

for Doctorate of Nursing Practice

Wright State University / University of Toledo 


\begin{abstract}
Objective: Cardiopulmonary resuscitation (CPR) performed on nursing home residents, consistently demonstrates poor outcomes with less than $5 \%$ survival rate (AMDA, January 30, 2011). Study participants overestimate CPR survival based on television and lack of accurate information (Adams \& Snedden, 2006; van Mil et al., 2000). This project evaluated use of a video decision tool on CPR choices in nursing home residents over three months.

Methods: A CPR video decision tool was added to advance care planning discussions as an audiovisual component to educate nursing home residents and their decision makers. Nurse Practitioners (NPs) documented the resident's choices in the electronic health record (EHR). Clinical metric reports, based on the EHR, were used to measure the change in CPR decisions over three months in seven nursing homes.
\end{abstract}

Significance: Health care spending is disproportionate at the end of life- $30 \%$ of Medicare expenditures are attributed to $5 \%$ of beneficiaries who die annually and $78 \%$ of costs are incurred in the final 30 days of life (Yu, 2008). Studies indicate a reduction in hospitalizations by increasing the use of advanced directives, surrogate decision makers and do not resuscitate decisions (Levy, Morris \& Kramer, 2008; Molloy et al. 2000; and Nicholas, Langa, Iwashyna \& Weir, 2011). Integration of a CPR video tool (Nous Foundation, 2010) into advance care planning, has the potential to reduce hospitalizations and health care costs, and ensure end of life care is consistent with resident wishes (Aw et al., 2012).

Results: The mean percentage change following implementation of the CPR video tool was $5.5 \%$ with $p=.226$. One facility closed during the pilot, one facility with a new NP showed an increase in residents requesting CPR and one of the eight facilities showed no change. The decrease in residents requesting CPR was not statistically signficant following integration of the CPR video tool. Despite the lack of statistical significance, a $5.5 \%$ reduction in residents selecting CPR with an equivalent reduction in hospitalizations would reduce medical expenses by $\$ 56,987$.

Keywords: CPR; Nursing Home; Video Decision Tool 


\section{Table of Contents}

Executive Summary (Abstract) 2

List of Tables $\quad 5$

List of Figures $\quad 5$

Problem Statement 6

Question of Study $\quad 8$

Theoretical Framework $\quad 8$

$\begin{array}{lr}\text { Evidence } & 12\end{array}$

Organizational Assessment 13

Critical Appraisal of Evidence $\quad 16$

Synthesis of Evidence $\quad 19$

Recommended Practice Change 27

Project Implementation 31

CPR Video Decision Toll Protocol 34

Evaluation Plan $\quad 35$

$\begin{array}{ll}\text { Data Analysis } & 37\end{array}$

Project Implementation Analysis $\quad 39$

$\begin{array}{ll}\text { Conclusion } & 41\end{array}$

References $\quad 43$

Appendices

Appendix A Literature Search Table $\quad 51$

Appendix B Studies Included and Excluded 53

Appendix C Organizational Readiness Survey $\quad 60$

Appendix D Invoice-1 $1^{\text {st }}$ Quarter, Nous 62 
Appendix E Invoice-remainder 2012, Nous 63

Appendix F Research Evaluation Table 64

Appendix G EBP Implementation Tool 83

Appendix H Sample Clinical Indicator Survey 86

Appendix I NP Implementation Survey $\quad 87$

Appendix J Post Implementation Call Log 88 


\section{List of Tables}

Table 1 Critical Apprisal of Evidence 16

$\begin{array}{lll}\text { Table } 2 \text { AGREE Guideline Evaluation } & 16\end{array}$

Table 3 Rapid Critical Appraisal of Systematic Review 18

Table $4 \quad$ Recommendations with Levels of Effectiveness 27

$\begin{array}{lll}\text { Table } 5 \quad \text { Evidence Synthesis } & 30\end{array}$

Table 6 Timeline for Project Implementation 32

$\begin{array}{lll}\text { Table } 7 & \text { Descriptive Statistics } & 38\end{array}$

Table $8 \quad$ Tests of Between Subjects Effects 38

\section{List of Figures}

Figure 1 Differences in Residents Requesting CPR by Facility 39 


\section{Problem Statement}

The public, as health care consumers, and clinicians, as health care providers, are dissatisfied with the current state of health care. Escalating cost, without demonstrated improvement in patient satisfaction and outcomes, is a frequent criticism of the health care system. Health care spending at the end of life is disproportionate--30\% of Medicare expenditures are attributed to $5 \%$ of the beneficiaries dying annually (Yu, 2008). End of life discussions with physicians reportedly reduce medical expenses in the last week of life by $\$ 1041$ per patient (Zhang et al., 2009). Yet, life-sustaining treatments in the final 30 days of life account for $78 \%$ of the total health care costs incurred during the last year of life (Yu, 2008) and only $17 \%$ of AARP respondents indicate having had a discussion about end of life decisions with their health care provider (HCP) (Nous Foundation, October 21, 2011).

This lack of advance directives leads to more aggressive treatment than may have been desired by the individual due to liability concerns by the provider thereby leading to an increase in health care costs (Duke, Yarbrough \& Pang, 2009; Nicholas et al., 2011). Advance directives are strongly associated with receiving medical care that is closely aligned with individual's stated wishes according to Silveira, Kim and Langa (2010). Clinicians report feelings of moral distress at providing care that they think inappropriate at end of life (Storch, 2006) including cardiopulmonary resuscitation (CPR) in situations that appear futile. Lazaruk (2006) questions why we are compelled to provide CPR with a "never give up" mindset and we fail to provide a respectful and dignified death. Gordon (2003) questions if the only "modus exitus" is failure to survive CPR! 
CPR performed on long term care residents, has been consistently shown to have poor outcomes with less than a five percent survival rate and several studies showing no survival (American Medical Directors Association, January 30, 2011). Lee, Angus and Abramson (1996) reported the cost of CPR for six month survivors ranging from $\$ 344,314$ to $\$ 966,759$ and conclude that while appropriate CPR is encouraged, blanket application appears extremely expensive. However, CPR continues to be considered a standard of care and is provided to everyone unless they have declined it through a Do Not Resuscitate (DNR) order (Adams \& Snedden, 2006; Gordon, 2003). Although the chance of surviving CPR is extremely low, nationally $60 \%$ of nursing home residents are considered full codes or should receive CPR when their heart stops (MessingerRapport \& Kamel, 2005). The organization implementing the proposed intervention fares better than the national statistic with $36.7 \%$ of residents requesting CPR. That metric still represents a significant opportunity to improve the provision of care to nursing home residents so that health care interventions correspond to their wishes, as well as to provide for a respectful and dignified death at the end of life, and reduce medical expenses. The public misconception that CPR is routinely successful has been fueled by television and inaccurate clinical information (van Mil et al, 2000; Adams \& Snedden, 2006; Gordon, 2003). Several studies have shown that nursing home residents who have advanced directives and DNR orders experience fewer hospitalizations, which reduces health care costs, with no change in mortality (Levy, Morris \& Kramer, 2008; Lopez, 2009; Molloy et al., 2000; Nicholas et al., 2011; Ouslander \& Berenson, 2011). Recognition of this opportunity to improve end of life care and decrease 
medical expenditures for nursing home residents, led to the development of the question of study.

\section{PICOT Question}

Do nursing home residents and their decision makers $(\mathrm{P})$ who use a CPR video decision tool (I), compared to nursing home residents and their decision makers who do not use the CPR video decision tool (C), choose CPR less frequently $(\mathrm{O})$ during a three month study $(\mathrm{T})$ ?

\section{Summary}

The proposed integration of a video CPR decision tool into the existing advance care planning discussions between the nurse practitioners, nursing home residents and their decision makers is projected to reduce the number of residents requesting CPR to less than the current $36.7 \%$ as a primary direct outcome measurement.

\section{Theoretical Framework-Organizational Process Change}

The Rosswurm and Larrabee (1999) model for evidence-based practice change emphasizes organizational process change which is applicable to this project as it would involve implementation of a practice guideline within the institutional special needs plan (ISNP) program through the nurse practitioners (NPs) managing the health care of members by working with physicians, nursing home staff and family members.

Step 1: Assess for need: The ISNP program metrics indicate that CPR is desired by $36.7 \%$ of patients versus $60 \%$ of nursing home residents nationally (Messinger-Rapport \& Kamel, 2005). While this metric compares favorably to the research--it still indicates an opportunity for improvement. Stakeholders include 
program and corporate leadership, NPs, nursing home staff, residents and families. These metrics are reviewed quarterly and interest exists in driving improvement.

Step 2: Locate evidence, plan and conduct search: A total of 16 studies including 1 systematic review, 4 Level II randomized controlled trials (RCTs), 1 Level III nonrandomized study and 10 qualitative studies met inclusion criteriapublished after 2000 and focused on nursing home residents' CPR decisions and interventions to impact those CPR decisions.

Step 3: Analyze the evidence: The strongest evidence involves a CPR video decision tool in conjunction with advanced care planning discussions. The ISNP program already includes advanced care planning discussions monthly and the CPR video decision tool will be added based on the evidence from the literature.

Step 4: Practice change: The CPR video decision tool will be added to the current advanced care planning discussions that occur monthly between the NP and the nursing home resident or decision maker. The discussion and decisions regarding CPR will continue to be documented in the EHR. This documentation system provides for reporting metrics to evaluate outcomes that do not identify residents individually—only as a composite facility calculation.

Step 5: Implement and evaluate: Six nursing homes with the highest rates of residents requesting CPR have been identified and the new guideline will be implemented. Initiating the project in a smaller subset of nursing homes (six) will ensure all the details of the process are functional. NPs are already allocated time for advance care planning discussions which are lengthy, so additional labor time is not anticipated. The CPR video decision tool will be shown to nursing 
home residents and decision makers via the NP's laptop computer. The CPR video decision tool may be accessed through the internet or it may be downloaded on the laptop if connectivity to the internet is problematic. All NPs would need extended-life batteries to support this function at $\$ 70$ per battery. Initially, three NPs will need the batteries for a total cost of $\$ 210$. Licensing costs for use of the video are $\$ 1000$ for the first quarter and $\$ 1500$ for the remainder of the year (April through December 2012). The average cost of a hospitalization in this ISNP program is $\$ 8015$ and two studies (Levy, Morris \& Kramer, 2008; and Molloy et al., 2000) demonstrate reduced hospital admissions through advance care planning and DNR orders. The potential exists to decrease health care costs through the use of this CPR video decision tool. Outcomes will be measured through the percentage of residents requesting CPR. This metric is reported on the quarterly clinical indicator reports by nursing home as a reporting function from the EHR where the NPs document CPR decisions.

Step 6: Integrate and maintain: The clinical indicator reports provide metrics for CPR by nursing home, ISNP program and nationally so outcomes can be measured, compared and the information disseminated to the NPs during monthly staff meetings and to other stakeholders during quarterly business reviews. Additional nursing homes will be evaluated for inclusion in the project after the first quarter. National stakeholders are considering implementation across the country dependent on the results achieved in the initial ISNP implementation. 


\section{Theoretical Framework—Decision Making}

Janis \& Mann's (1977) decisional conflict is a useful theory in examining end of life decisions, decision making by surrogates, and medical treatment decision making. The basic tenets of decisional conflict theory include: Hot and cold decisions; vigilant information processing; coping patterns; outworn decisions; and the balance sheet decision making tool. Hot and cold decisions are described as situational in nature and stressful—decisions that must be made in the 'heat of the moment' and there is little time for investigation and reflection or there is significant weight attached to the outcome of the decision. Conversely, cold decisions are not emotional or immediate and are not stressful. Vigilant information processing refers to the process an individual uses to make decisions including obtaining information, discussions with others, other viewpoints and attaching weight to various aspects. Vigilant information processing is associated with high satisfaction in the ultimate decision. Coping patterns are reflected in perception of risk associated with the decision and consideration of possible outcomes. Outworn decisions no longer reflect the situation or current realities and must be reevaluated. Janis and Mann's (1977) balance sheet decision making tool incorporates assessment of all alternatives available including positive and negative associations for the self, others and community. This theoretical framework underscores the use of the CPR video decision tool as a component of vigilant information processing which may lead to improved satisfaction with the decision. 


\section{Evidence}

Databases searched included Cumulative Index of Nursing and Allied Health Literature (CINAHL), PubMed, Medline, and the Cochrane Database of Systematic Reviews (CDSR). These databases were selected as they provided a wide representation of different journals covering many disciplines. This method provides for an exhaustive literature search on the topic and was completed in March 2011 and updated again in October 2011 and August 2012. Key words searched were: CPR and decision aid; decision aid; decision tool; older adult; geriatric*; CPR; CPR and elder*; CPR and age group; decision aid and elder*; decision aid and code; end of life and CPR; end of life and CPR and decision aid; and advance directive was added at the guidance of one member of the project team.

Initially English language was set as a limit but this was removed following the guidance of one member of the project team, however, no studies requiring translation were identified for inclusion. (Refer to Appendix A for literature search tables).

Inclusion criteria were defined for the literature search as publication date 2000 or later and the topic related to the question of study: CPR decision aid for nursing home residents or surrogate decision makers for nursing home residents, and advance directives. As the project evolved and the evidence was analyzed, advance directive studies were excluded. These studies provided excellent background information but the CPR studies were more directly related to the question of study. Therefore, exclusion criteria were defined as studies published prior to 2000 and studies not directly related to the question of study. 
Studies of CPR based on arrests or protocols in the acute care environment were excluded as this literature review focused on nursing home residents-a different population of interest. Details of studies included and excluded are available in Appendix B.

\section{Organizational Assessment}

The organizational needs assessment indicates it is "ready to go" based on Melnyk and Fineout-Overholt's Organizational Culture and Readiness for System-Wide Integration of Evidence-based Practice Survey (2011, p 559). This completed tool is available in Appendix C. The organization clearly subscribes to evidence-based practice and it is supported at the senior operational leadership level, the medical directors and this particular program employs only advanced practice nurses-NPs, so even at the staff level, there is engagement and support for research and implementation of research-based findings. Fiscal support is available for workshops, conferences and continuing education. Work time can be used to research and develop projects. The Center for Nursing Advancement is led by a doctorally prepared nurse researcher and three other nurses within the corporate leadership are doctorally prepared. Due to the nature of the "staff" all being NPs, all of the leadership team are also Master's prepared nurses. The only item on the needs assessment that is absent in this organization is the librarian support, but subscriptions to Up to Date are paid for by the organization so access is not an issue. Dissemination of research is supported through publications, presentations and poster presentations. Conference fees, travel and hotel stays are also reimbursed by the organization. 
Therefore, the development and implementation of an evidence-based project within this organization is supported and encouraged.

The internal project sponsor and stakeholder is the Chief Nursing Officer (CNO). The proposal was presented during a quarterly business review as a method to better align nursing home residents end of life wishes with care, as well as to reduce hospital admissions by overcoming misperceptions about the success of CPR. The CNO described it as "benevolent assault" and there was widespread agreement among senior leadership that decreasing the residents requesting CPR had the potential to decrease hospital admissions without impacting mortality (Molloy et al., 2000; Ouslander \& Berenson, 2011). This ISNP program is funded by Centers for Medicare Services (CMS) and is paid a monthly fee based on the diagnoses of the resident. This monthly reimbursement must be managed to cover all medical expenses incurred by the resident. The ISNP program is at risk so if medical expenses exceed the monthly reimbursement, the ISNP program absorbs the additional medical expense. Reduced medical expense is the key driver for the ISNP program stakeholders. The key driver for the NP and nursing home staff stakeholders is the alignment of care with resident wishes. Caregivers experience moral distress in providing CPR to residents with little likelihood of surviving and not providing a dignified death (Lazaruk, 2006). The key drivers for nursing home residents and their decision makers are autonomy in making those decisions and alignment of end of life care choices with the provision of that care (Aw et al., 2011). Identifying all stakeholders and the key drivers specific to each group is critical to 
the successful development and implementation of the CPR video decision tool project.

Barriers to implementation could be lack of resident or decision maker participation in CPR discussions and advance care planning. The absence of an identified decision maker for residents who lack decisional capacity is also a barrier. Collaboration with the social worker may be a method to overcome this barrier and locate a suitable decision maker. The perceived time commitment by NPs to show the CPR video decision tool during the advance care planning discussion, which is 2 minutes 33 seconds, could be a barrier as well as reluctance to introduce a video into the conversation. This could be overcome with education on evidence to support use of a video decision tool. The subscription for access to the CPR video is being negotiated, but connectivity to the internet to access the web-based version could be a barrier in some nursing homes. A strategy to overcome the connectivity issue could be downloading the video to the NP's laptop so that internet connectivity is unnecessary. Dr. Volandes suggested this approach for the implementation of the CPR video decision tool.

Cost benefit analysis includes the expense of the CPR video decision tool subscription which is $\$ 1000$ for the first quarter, followed by $\$ 1500$ for the remainder of 2012 (Appendix D and Appendix E). The subscription cost of the video is based on the number of lives covered by the ISNP. The cost of the extended life batteries for each of eight NPs is $\$ 70$. The total expenses to start are $\$ 1,570$ for the initial 90 day period which includes $\$ 10$ for mailing. One hospital admission averages $\$ 8,015$ for the ISNP program. The cost associated 
with the project implementation is only a fraction of the medical expense saved if even one hospitalization is avoided. There is not additional labor required as time for advanced care planning discussions is already planned into the NPs' work day.

\section{Critical Appraisal of Evidence}

Twenty studies were selected including one identified through a hand search of references cited in selected articles and listed in Table 1 with levels of evidence (see detailed Research Evaluation Table Appendix F).

\section{Table 1 Critical Appraisal of Evidence}

\begin{tabular}{|c|c|c|c|c|c|c|}
\hline Level 1 & Level II & Level III & Level IV & Level V & Level VI & Level VII \\
\hline 1 & 4 & 2 & 6 & 1 & 6 & 0 \\
\hline
\end{tabular}

One guideline was located but was not included following evaluation of the protocol using the AGREE tool (Table 2). The protocol Interventions for Promoting the Use of Advance Directives for End-of-Life Decisions in Adults (Simon-Lorda et al., 2008) was evaluated using the AGREE tool (Table 2) with scoring based on $4=$ strongly agree and $1=$ strongly disagree.

It is an outline of what is to be done to establish the protocol but there are no actual guidelines despite being published in 2008 and re-evaluated in October 2011 with the same results. This was also confirmed with the librarian as the lack of results and recommendations was surprising. 


\section{Table 2 AGREE Guideline Evaluation of Promoting the Use of Advanced Directives for End-of-Life Decisions in Adults:}

\begin{tabular}{|c|c|c|}
\hline Dimension & Score & Comments \\
\hline 1. Overall objective specifically described & 4 & $\begin{array}{l}\text { Assess effects of interventions } \\
\text { for promoting use of advance } \\
\text { directives about end-of-life } \\
\text { decisions of adults }\end{array}$ \\
\hline 2. Clinical question described & 3 & $\begin{array}{l}\text { Conceptual \& historical } \\
\text { background described }\end{array}$ \\
\hline 3. Population & 4 & $\begin{array}{l}\text { Adults—not specifically over } 65 \\
\text { yr or nursing home residents }\end{array}$ \\
\hline $\begin{array}{l}\text { 4. Development group includes representatives } \\
\text { from all stakeholder groups }\end{array}$ & 1 & $\begin{array}{l}\text { It is an incomplete protocol at } \\
\text { this point in time and this was } \\
\text { not addressed }\end{array}$ \\
\hline 5. Patients' views and preferences sought & 4 & $\begin{array}{l}\text { Four organizations had } \\
\text { submitted consumer-oriented } \\
\text { feedback and plans were } \\
\text { described for obtaining more }\end{array}$ \\
\hline 6. Target users defined & 1 & $\begin{array}{l}\text { It is an incomplete protocol at } \\
\text { this point in time and this was } \\
\text { not addressed }\end{array}$ \\
\hline 7. Guideline piloted & 1 & $\begin{array}{l}\text { It is an incomplete protocol at } \\
\text { this point in time and this was } \\
\text { not addressed }\end{array}$ \\
\hline $\begin{array}{l}\text { 8. Systematic methods used to search for } \\
\text { evidence }\end{array}$ & 4 & Plan was described in detail \\
\hline $\begin{array}{l}\text { 9. Criteria for selecting evidence clearly } \\
\text { described }\end{array}$ & 4 & $\begin{array}{l}\text { Selection criteria described in } \\
\text { detail }\end{array}$ \\
\hline $\begin{array}{l}\text { 10. Methods for formulating recommendations } \\
\text { clearly described }\end{array}$ & 2 & $\begin{array}{l}\text { Method for data extraction, data } \\
\text { analysis, data management and } \\
\text { risk bias described in detail but } \\
\text { no actual recommendations }\end{array}$ \\
\hline 11. Benefits, side effects and risks considered & 2 & $\begin{array}{l}\text { Protocol is incomplete but } \\
\text { historical background included } \\
\text { some considerations }\end{array}$ \\
\hline $\begin{array}{l}\text { 12. Explicit link between recommendations and } \\
\text { supporting evidence }\end{array}$ & 1 & $\begin{array}{l}\text { No recommendations-- It is an } \\
\text { incomplete protocol at this point } \\
\text { in time and this was not } \\
\text { addressed }\end{array}$ \\
\hline 13. Guideline externally reviewed by experts & 1 & It is not yet published \\
\hline 14. Procedure for updating guideline discussed & 1 & $\begin{array}{l}\text { It is an incomplete protocol at } \\
\text { this point in time and this was } \\
\text { not addressed }\end{array}$ \\
\hline $\begin{array}{l}\text { 15. Recommendations are specific and } \\
\text { unambiguous }\end{array}$ & 1 & $\begin{array}{l}\text { There are no recommendations } \\
\text { at this point in time. }\end{array}$ \\
\hline $\begin{array}{l}\text { 16. Different options for management of } \\
\text { condition are clearly presented }\end{array}$ & 1 & $\begin{array}{l}\text { It is an incomplete protocol at } \\
\text { this point in time and this was }\end{array}$ \\
\hline
\end{tabular}




\begin{tabular}{|c|c|c|}
\hline & & not addressed \\
\hline $\begin{array}{l}\text { 17. Key recommendations are clearly } \\
\text { identifiable }\end{array}$ & 1 & $\begin{array}{l}\text { It is an incomplete protocol at } \\
\text { this point in time and this was } \\
\text { not addressed }\end{array}$ \\
\hline $\begin{array}{l}\text { 18. Guideline is supported with tools for } \\
\text { application }\end{array}$ & 1 & $\begin{array}{l}\text { It is an incomplete protocol at } \\
\text { this point in time and this was } \\
\text { not addressed }\end{array}$ \\
\hline 19. Organizational barriers are discussed & 2 & $\begin{array}{l}\text { Barriers are discussed only from } \\
\text { an historical perspective }\end{array}$ \\
\hline 20. Cost implications are considered & 2 & $\begin{array}{l}\text { Cost is considered from an } \\
\text { historical perspective }\end{array}$ \\
\hline $\begin{array}{l}\text { 21. Guideline presents key review criteria for } \\
\text { monitoring or auditing purposes }\end{array}$ & 1 & $\begin{array}{l}\text { It is an incomplete protocol at } \\
\text { this point in time and this was } \\
\text { not addressed }\end{array}$ \\
\hline $\begin{array}{l}\text { 22. Guideline is editorially independent from } \\
\text { the funding body }\end{array}$ & 1 & $\begin{array}{l}\text { It is an incomplete protocol at } \\
\text { this point in time and this was } \\
\text { not addressed }\end{array}$ \\
\hline $\begin{array}{l}\text { 23. Conflicts of interest of guideline } \\
\text { development members is disclosed }\end{array}$ & 4 & None known \\
\hline $\begin{array}{l}\text { Overall Assessment: Would not recommend } \\
\text { but would consider in the future when } \\
\text { completed }\end{array}$ & & $\begin{array}{l}\text { Although published in } 2008 \text {, the } \\
\text { protocol is an outline of what is } \\
\text { to be done and is not the actual } \\
\text { protocol at this point. This was } \\
\text { confirmed with the nursing } \\
\text { librarian since due to time lapse, } \\
\text { lack of concluding } \\
\text { recommendations was } \\
\text { surprising. }\end{array}$ \\
\hline
\end{tabular}

One systematic review was identified in the literature review. The Rapid Critical Appraisal of Systematic Reviews of Clinical Interventions / Treatments

(Fineout-Overholt, \& Melnyk, 2005) (Table 3) was completed on Ramsaroop,

Reid and Adelman's 2007 publication, Completing an Advance Directive in the

Primary Care Setting: What Do We Need for Success?

Table 3: Rapid Critical Appraisal of Systematic Reviews

\begin{tabular}{|l|l|}
\hline $\begin{array}{l}\text { The Rapid Critical Appraisal of Systematic } \\
\text { Reviews of Clinical Interventions / Treatments }\end{array}$ & \\
\hline 1. Are the results of the review valid? & Yes \\
\hline $\begin{array}{c}\text { a. Are the studies in the review randomized } \\
\text { controlled trials? }\end{array}$ & $\begin{array}{l}\text { Most--12 of 18 RCTs; } 2 \\
\text { quasi-experimental, } 2 \\
\text { prospective trials \& 1 }\end{array}$ \\
\hline
\end{tabular}




\begin{tabular}{|c|c|}
\hline & observational study \\
\hline $\begin{array}{l}\text { b. Does the review include a detailed description } \\
\text { of the search strategy to find all relevant studies? }\end{array}$ & $\begin{array}{l}\text { Yes, search is detailed } \\
\text { with inclusion \& exclusion } \\
\text { criteria }\end{array}$ \\
\hline $\begin{array}{l}\text { C. Does the review describe validity of individual } \\
\text { studies? }\end{array}$ & $\begin{array}{l}\text { Yes, validity of individual } \\
\text { studies was addressed }\end{array}$ \\
\hline d. Were the results consistent across studies? & $\begin{array}{l}\text { Yes, based on } \\
\text { intervention, i.e. mailed } \\
\text { information to patients had } \\
\text { no effect but all studies } \\
\text { with additional discussion / } \\
\text { meeting / visit had positive } \\
\text { results }\end{array}$ \\
\hline $\begin{array}{l}\text { e. Were individual patient data or aggregate data } \\
\text { used in the analysis? }\end{array}$ & Aggregate data was used \\
\hline 2. What were the results? & positive w/ \\
\hline $\begin{array}{l}\text { a. How large is the intervention or treatment } \\
\text { effect? }\end{array}$ & $\begin{array}{l}\text { Moderately positive-5 } \\
\text { studies achieved effect } \\
\text { sizes }>.5 \text { but }<.8 ; 1 \text { study } \\
\text { had effect size } 2.48 \text { (VA } \\
\text { group intervention study) } \\
\text { Effect size } 1.15 \text { for pool }\end{array}$ \\
\hline $\begin{array}{l}\text { b. How precise is the intervention or treatment } \\
(\mathrm{CI}) \text { ? }\end{array}$ & $\begin{array}{l}\text { Not very precise--Cl was } \\
95 \% \text { but wide range } .52- \\
1.77\end{array}$ \\
\hline $\begin{array}{l}\text { 3. Will the results assist me in caring } \mathrm{fc} \\
\text { patients? }\end{array}$ & Yes \\
\hline $\begin{array}{l}\text { a. Are my patients similar to the ones included in } \\
\text { the review? }\end{array}$ & Yes-adults age $\geq 18$ \\
\hline $\begin{array}{l}\text { b. Is it feasible to implement the findings in my } \\
\text { practice setting? }\end{array}$ & $\begin{array}{l}\text { Yes-discussions } \\
\text { between HCP \& patient } \\
\text { over multiple visits }\end{array}$ \\
\hline $\begin{array}{l}\text { c. Were all clinically important outcomes } \\
\text { considered, including risks and benefits of the } \\
\text { treatment? }\end{array}$ & $\begin{array}{l}\text { Yes, outcomes were } \\
\text { considered }\end{array}$ \\
\hline $\begin{array}{l}\text { d. What is my clinical assessment of the patient } \\
\text { and are there any contraindications or circumstances } \\
\text { inhibiting me from implementing the treatment? }\end{array}$ & $\begin{array}{l}\text { Emotional instability could } \\
\text { be a contraindication but } \\
\text { over multiple visits could } \\
\text { be overcome }\end{array}$ \\
\hline $\begin{array}{l}\text { e. What are my patient's and family } p \\
\text { and values about the treatment under cor }\end{array}$ & Assessed per discussion \\
\hline
\end{tabular}

(Fineout-Overholt, \& Melnyk, 2005) 


\section{Synthesis of Evidence}

CPR is a primary component of advance directives so many studies examined interventions leading to the outcome of the completion of an advanced directive. Ramsaroop, Reid and Aldelman (2007) published a systematic review and meta-analysis which examined 18 studies demonstrating moderately successful interventions to increase the completion of advanced directives involving multiple patient / health care professional (HCP) interactions over a period of time (unadjusted pool effect size was $0.50 ; 95 \% \mathrm{Cl}=0.17-0.83$ ). They also concluded that simply distributing written material did not increase the completion of advanced directives which is commonly the method employed in nursing homes.

Three of four Level II randomized control trials (RCTs) were conducted by Dr. Angelo Volandes, MD, with various co-authors. Two additional Level III studies were also conducted by Dr. Volandes, MD, but lacked randomization in the methodology. The format for the RCTs included a narrative presented by a trained researcher followed by a short video segment of two to six minutes. The sample sizes ranged from 14 to 200 and included rural and suburban populations.

Volandes et al. (2012) found that decisions regarding CPR and the use of ventilation in poor prognosis cancer patients changed significantly after viewing a video decision aid. Seventy-one percent of study participants wanted CPR prior to viewing the video decision aid compared to $62 \%$ following $(p=.03)$. Eighty percent of study participants wanted ventilation compared to $67 \%$ after viewing the video decision aid $(p=.008)$. The study noted patients perceived an 
increased knowledge of goals of care and likelihood of resuscitation after viewing the video $(p<.001)$. Despite the decisions voiced by these study participants, only $5 \%$ had documented do-not-resuscitate orders in the medical record (kappa $-0.01 ; 95 \% \mathrm{Cl}-0.06$ to 0.04$)$.

Volandes et al. (2011) demonstrated the video group was more likely to select comfort care measures (odds ratio $3.9,95 \% \mathrm{Cl}=1.0-15.1$ ). This study also indicated greater health literacy was positively correlated with increased selection of comfort care.

Volandes, Barry, Chang and Paasche-Oslow (2010) demonstrated in a nonrandomized controlled trial that use of a video decision aid reduced uncertainty as measured for decisional conflict and the impact was greater for those with lower health literacy $(p<.0001)$. Decision making was shown to be more stable over time with the video intervention group-- $6 \%$ change at 6 weeks versus the non-video group with $29 \%$ change, $p<.001$ (Volandes, PaascheOslow, et al., 2009).

Volandes, Mitchell, Gillick, Chang, and Paasche-Oslow (2009) examined concordance between the patient and surrogate decision maker in a subgroup of an ongoing study $(n=14)$. Concordance was $33 \%$ in the non-video group compared to $100 \%$ in the video group. The researchers also assessed acceptability of the video as an intervention with positive results--94\% would recommend the video to others (Volandes, Mitchell et al., 2009) and 31/33 found the video very or somewhat helpful with $32 / 33$ recommending it to others (Volandes, Mitchell et al., 2009). 
The Let Me Decide (LMD) advance directive program was the intervention in a RCT by Molloy et al. (2000) in Ontario. This study demonstrated a $49 \%$ completion rate of advance directives by decisional residents of nursing homes and $78 \%$ completion rate by families of residents who were not decisional. Molloy et al. (2000) found no statistical difference in satisfaction between the group completing advance directives and the group not completing advance directives. This study demonstrated fewer hospitalizations in the intervention group -0.27 hospitalizations compared to $0.48, p=.001$, reduced utilization of services with no change in satisfaction or mortality $(p=.20)$ and reduced resource cost $(p=.01)$ (Molloy et al., 2000).

Regional variation in the use of advance directives and Medicare end-oflife expenditures was examined through a retrospective observational study by Nicholas, Langa, Iwashyna and Weir (2011). Hospital regions were grouped into high, medium and low spending, although details were not provided as to how groups were divided. Advanced directives specifying limitations for end-of-life care significantly reduced medical expenses by $\$ 5585$ per decedent $(95 \% \mathrm{Cl}$ $\$ 10903$ to $-\$ 267)$ in high regions, but did not demonstrate an impact in medium or low spending regions (Nicholas et al., 2011). Advanced directives were also associated with less likelihood of dying in a hospital in both high $(-9.8 \%$; $95 \%$ $\mathrm{Cl}=-16 \%$ to $-3 \%)$ and medium spending regions $(-5.3 \% ; 95 \% \mathrm{Cl}=-10 \%$ to $-0.4 \%$ ) (Nicholas et al., 2011). Advanced directives were associated with higher hospice use in high- and medium-spending regions $(17 \% ; 95 \% \mathrm{Cl}=11 \%$ to $23 \%$ in high spending regions; $11 \% ; 95 \% \mathrm{Cl}=6 \%$ to $16 \%$ in medium spending regions), but not in low-spending regions (Nicholas et al., 2011). 
Two studies followed a quality improvement effort to increase completion of advanced directives. Levy, Morris and Kramer (2008) implemented Making Advance Planning a Priority (MAPP) and compared one year before and one year after the project implementation. This program included identifying residents at $50 \%$ or greater risk of death in the following twelve months, and notifying the physician via fax and chart flag. The physician had four options to respond: End-of-life needs had already been addressed and the date of the progress note documenting that; state it would be addressed on the next visit and give the date of the visit; refer the resident for a palliative care consult; or refer the resident for a hospice consult. This intense follow-up resulted in an additional eighteen advanced directive completions. The results of this quality improvement project included a significant reduction in residents dying in the hospital from $48.2 \%$ to $8.9 \%(p=.0001), 100 \%$ of residents dying after the project implementation had advanced directives executed, and an increase in DNR from $63 \%$ to $84.4 \%(p=.003)$ (Levy, Morris \& Kramer, 2008). No discussion of reduced health care costs was included but a reduction in residents dying in the hospital obviously reduces health care expenditures in an already overburdened system.

McBee, Burack, Carter and Chichin (2000) published the results of a quality improvement project designed to increase the completion of advance directives on three units of a New York City nursing home. They demonstrated the majority of families made decisions with four or fewer contacts; $80 \%$ decided within one month of contact and $40 \%$ of families made decisions at the time of 
contact (McBee et al., 2000). This publication did not indicate if the resident was decisional and only described the contact as a phone call.

Frank, Pichora, Suurdt and Heyland (2010), Sudore and Fried (2010), and Johnson and Nelson (2008) all demonstrated increased completion of advanced directives through multiple discussions between health care providers and patients. Sudore and Fried (2010) focused on selection of a decision maker as the advanced directive criteria while Frank et al. (2010) focused on CPR decisions. Johnson and Nelson (2008) included a written material with the discussions.

One study reported $90 \%$ of subjects thought advanced directives made it easier to ensure that end-of-life wishes were followed (Matzo, Hijjazi \& Outwater, 2008) and two studies indicated alignment of care with the patient's preference was improved through an advanced directive (Silveira, Kim \& Langa, 2010; Anderson, Sikorski \& Finucane, 2006).

Barriers to completing an advanced directive included lack of time or completion not being a priority and lack of knowledge or denial of health status knowledge (Aw et al., 2012; Barnes, Jones, Tookman \& King, 2007; Fried et al., 2010; Jezewski \& Meeker, 2005). Thorevska et al. (2005) described subjects who had completed a living will as more likely to be white, Protestant and highly educated. Messinger-Rapport and Kamel (2005) described age $(p=.017)$ and race $(p=.011)$ as the only predictors for completion of a DNR. Hirschman, Abbott, Hanlon, Bettger and Naylor (2012) identified predictors of having a living will as using long term care services in assisted living ( $O R=5.01, p<.001)$, white $(\mathrm{OR}=2.87, \mathrm{p}<.001)$, greater than 12 years of education $(\mathrm{OR}=2.50, \mathrm{p}<.001)$ and 
having experienced a significant change in health status in the previous six months $(\mathrm{OR}=1.97, \mathrm{p}=.007)$. They also identified predictors of having a health care power of attorney as receiving long term care services in an assisted living $(\mathrm{OR}=4.66, \mathrm{p}<.001)$, greater than 12 years of education $(\mathrm{OR}=1.74, \mathrm{p}=.022)$ and having experienced a significant change in health status in the previous six months (OR=1.61, $\mathrm{p}=.037$ ) (Hirschman et al., 2012). Thorevska et al. (2005) found $80 \%$ of African American patients were more likely to "not trust the doc" and want all life-sustaining measures, and Hispanics were 2.5 times as likely as nonHispanics to prefer all life-sustaining treatments. The prevalence of DNR ranged from 40\% to $71 \%$ (Adams \& Snedden, 2006; Anderson, Sikorski \& Finucane, 2006; Hirschman et al., 2012; Levy, Morris \& Kramer, 2008; Matzo, Hijjazi \& Outwater, 2008; Messinger-Rapport \& Kamel, 2005).

Dipko, Xavier and Kohlwes (2003) studied 13,913 VA patients using a group education intervention in which 203 subjects participated. While their conclusion was that group education was twice as effective as individual sessions and less time-consuming, the fact that only 203 chose to participate of 13,913 patients (1\%) was not discussed.

A knowledge deficit was noted to be a factor in the lack of advance directives and DNR decisions. Several studies indicated subjects over-estimated the success of CPR (van Mil et al., 2000). Laakkonen, Pitkala, Strandberg, Berglind and Tilvis (2005) studied 220 elderly, community-dwelling subjects in Finland $-40 \%$ presumed the outcome of CPR to be good or moderately good, and $52 \%$ estimated the outcome as better than those subjects refusing CPR (Laakkonen et al., 2005). Adams and Snedden (2006) surveyed 100 patients 
and $81 \%$ of the subjects believed the chances of surviving CPR and leaving the hospital were greater than $50 \%$ and $23 \%$ thought the chances were greater than $90 \%$ ! Studies have shown the survival rate less than $5 \%$ with several studies reporting no survivors (American Medical Directors Association, January 30, 2011). Television was determined to be the primary method of obtaining information related to advance directives and CPR (Adams \& Snedden, 2006; Cherniack, 2002; and Van Mil et al., 2000) while only 7\% involved a physician in the development of advance directives (Thorevska et al., 2005).

Physician consensus with patient advance directives was examined by Levi, Heverley and Green (2011) by studying physician decision making with 19 patients who had created advance directives using a computer-based decision aid. Three physicians made five or six clinical decisions in simulated end-of-life scenarios based on the patient's advance directive. The computer-based decision aid resulted in $84 \%$ consensus between patient wishes and physician treatment orders (Levi, Heverley \& Green, 2011). Concensus on the use of mechanical ventilation was $82 \%$ and the use of CPR was $75 \%$ (Levi, Heverley \& Green, 2011).

The content of the advance care planning discussion and CPR choices was studied by Mallery, Hubbard, Moorhouse, Koller and Eeles (2011) in a qualitative interview design with 28 physicians. They concluded that there is wide variation in the content of the discussion--that $75 \%$ of the physicians did not contextualize the CPR decision within the individual's situation or illness burden; $79 \%$ did not check the patient's understanding; $82 \%$ did not inquire about 
existing advance directives and $96 \%$ did not comprehensively discuss illnesses with life expectancy (Mallery et al., 2011).

The literature review supports the use of a video decision tool as an enhancement to routine advanced care planning discussions between the NP, resident and decision maker(s) leading to decreased selection of CPR (increased selection of DNR).

\section{Recommended Practice Change}

The recommended practice change integrates individual presentations of the CPR video decision tool as part of the advance care planning discussion between the NP and the resident or decision maker(s). The NP reviews the advance care plan at least monthly with residents and / or their decision maker as part of the ISNP program. The NP would show the CPR video decision tool on their laptop as part of the individual discussion, answer questions, further educate around the individual's specific health conditions and discuss the impact of CPR within the individualized advance care plan. The NP will document discussions and decisions in the EHR. Outcomes will be measured through the clinical indicator studies (CIS) which summarize CPR status as a percentage by facility from the EHR. This can be compared to the percentage of residents choosing CPR before and after the intervention.

\section{Scope}

Disease / Condition: CPR decision making in nursing home residents Clinical Specialty: Geriatrics, Family Practice, Psychology, Internal Medicine Intended Users: Physicians, Advanced Practice Nurses, Physician Assistants, Nurses, Social Workers, Psychologists 
Objective: Decrease the number of residents in nursing homes requesting CPR and improve alignment of end of life decisions with the provision of desired care

Target Population: nursing home residents enrolled in the ISNP program

Table 4: Recommendations with Level of Effectiveness

\begin{tabular}{|c|c|c|}
\hline $\begin{array}{c}\text { Statement of } \\
\text { Recommendation }\end{array}$ & Reference(s) & $\begin{array}{c}\text { Level of } \\
\text { Effectiveness }\end{array}$ \\
\hline $\begin{array}{l}\text { Facilitate multiple } \\
\text { advance care planning } \\
\text { discussions with } \\
\text { patients and decision } \\
\text { makers regarding } \\
\text { completion of advance } \\
\text { directives }\end{array}$ & $\begin{array}{l}\text { Ramsaroop, Reid \& Adelman (2007) } \\
\text { Level I } \\
\text { VanMil, et al (2000) Level VI } \\
\text { Laakkonen et al (2005) Level VI } \\
\text { Levy, Morris \& Kramer (2008) Level IV } \\
\text { McBee \& et al (2000) Level VI } \\
\text { Sudore \& Fried (2010) Level V } \\
\text { Dipko, Xavier \& Kohlwes (2003) Level } \\
\text { IV }\end{array}$ & A1 \\
\hline $\begin{array}{l}\text { Utilize video decision } \\
\text { aid to assist } \\
\text { explanation to patient \& } \\
\text { family }\end{array}$ & $\begin{array}{l}\text { Volandes, Paasche-Oslow, Barry, } \\
\text { Gillick, Minaker, Chang, Cook, Abbo, } \\
\text { El-Jawahri, \& Mitchell (2009) } \\
\text { Volandes, Mitchell, Gillick, Change, } \\
\text { Paasche-Oslow (2009) } \\
\text { Volandes, Barry, Chang, Paasche- } \\
\text { Oslow (2010) } \\
\text { Volandes, Ferguson, Davis, Hull, } \\
\text { Green, Chang, Deep, Paasche-Oslow } \\
\text { (2011) } \\
\text { Volandes, Levin, Slovin, Carvajal, } \\
\text { O'Reilly, Keohan....Noy (2012) }\end{array}$ & A2 \\
\hline
\end{tabular}

Level of effectiveness key: $A 1=e v i d e n c e$ from meta-analysis or systematic review; $A 2=e v i d e n c e$ from RCT; B1=evidence from high quality evidence-based practice guideline; $B 2=$ evidence from quasi-experimental studies; $\mathrm{C} 1=$ =vidence from observational studies; $\mathrm{C} 2=$ =inconsistent evidence from observational or controlled trials; $D=$ evidence from expert opinion, case reports or national consensus reports.

\section{Applicability}

The project proposal to integrate the video CPR decision tool into the existing advance care planning discussions between nursing home residents / their decision makers and the NP is supported by the existing evidence (Table 5, Evidence Synthesis). The evidence indicates the project proposal can lead to a reduction in the percentage of residents choosing CPR. 
This proposal has the potential to also indirectly reduce medical expenses as studies indicate that nursing home residents who have selected DNR have fewer hospitalizations with no change in mortality (Molloy et al., 2000; Ouslander \& Berenson, 2011). There is strong stakeholder support for implementation of the project and the initial expense is minimal compared to the average cost of hospitalizations. Benefits to the nursing home resident include autonomy to make decisions and improved alignment of care provided with care desired, as well as improved understanding of the actual outcomes of CPR. Risks include the perception that CPR should not be provided solely due to costs or as a form of ageism. There is a significant lack of understanding that CPR is rarely successful in nursing home residents because of the underlying chronic illnesses that precipitate the need to live in a nursing home, and that biological age is a more sensitive indicator than chronological age for effectiveness of CPR. The CPR video decision tool has been studied in nursing home residents and has been well-received. It can be an audiovisual tool in the NP's arsenal of educational interventions. 
Table 5: $\quad$ Evidence Synthesis-CPR Interventions

\begin{tabular}{|c|c|c|c|c|c|c|c|c|c|}
\hline $\begin{array}{l}\text { Studies } \\
\text { Interventions }\end{array}$ & Ramsaroop & $\begin{array}{l}\text { Volandes, } \\
\text { Paasche- } \\
\text { Oslow } \\
2009\end{array}$ & $\begin{array}{c}\text { Volandes, } \\
\text { Mitchell } \\
2009\end{array}$ & $\begin{array}{c}\text { Volandes, } \\
\text { Barry } \\
2010\end{array}$ & $\begin{array}{c}\text { Volandes, } \\
\text { Ferguson } \\
2011\end{array}$ & $\begin{array}{l}\text { Volandes, } \\
\text { Levin } \\
2012\end{array}$ & $\begin{array}{c}\text { Molloy, et al } \\
2000\end{array}$ & $\begin{array}{c}\text { Johnson \& } \\
\text { Nelson } \\
2008\end{array}$ & $\begin{array}{c}\text { Frank, } \\
\text { Pichora, et } \\
\text { al } \\
2009\end{array}$ \\
\hline $\begin{array}{l}\text { Video decision } \\
\text { tool }\end{array}$ & & $X$ & $\mathrm{X}$ & $\mathrm{X}$ & $\mathrm{X}$ & $\mathrm{X}$ & & & \\
\hline $\begin{array}{l}\text { Discussion w/ } \\
\text { Health Care } \\
\text { Professional } \\
\text { individually }\end{array}$ & $\mathrm{X}$ & $\mathrm{X}$ & $\mathrm{X}$ & $\mathrm{X}$ & $\bar{X}$ & $\mathrm{X}$ & $\mathrm{X}$ & $\mathrm{X}$ & $\mathrm{X}$ \\
\hline $\begin{array}{l}\text { Discussion w/ } \\
\text { Health Care } \\
\text { Professional in } \\
\text { group }\end{array}$ & & & & & & & & & \\
\hline $\begin{array}{l}\text { Written } \\
\text { material w/ } \\
\text { discussion }\end{array}$ & $X$ & & & & & & & $X$ & $X$ \\
\hline
\end{tabular}

Evidence Synthesis Table CPR Interventions--Continued

\begin{tabular}{|c|c|c|c|c|c|c|c|c|}
\hline $\begin{array}{l}\text { Studies } \\
\text { Interventions }\end{array}$ & $\begin{array}{l}\text { Laakkonen et } \\
\text { al } \\
2005\end{array}$ & $\begin{array}{l}\text { Levy, } \\
\text { Morris \& } \\
\text { Kramer } \\
2008\end{array}$ & $\begin{array}{c}\text { McBee, et } \\
\text { al } \\
2000\end{array}$ & $\begin{array}{c}\text { Sudore \& } \\
\text { Fried } \\
2010\end{array}$ & $\begin{array}{l}\text { Barnes et al } \\
2007\end{array}$ & $\begin{array}{c}\text { Dipko, Xavier \& } \\
\text { Kohwles } \\
2003\end{array}$ & $\begin{array}{c}\text { Mallery, } \\
\text { Hubbard, et } \\
\text { al } \\
2011 \\
\end{array}$ & $\begin{array}{l}\text { van Mil } \\
\text { et al } \\
2000\end{array}$ \\
\hline \multicolumn{9}{|l|}{$\begin{array}{l}\text { Video decision } \\
\text { tool }\end{array}$} \\
\hline $\begin{array}{l}\text { Discussion w/ } \\
\text { Health Care } \\
\text { Professional } \\
\text { individually }\end{array}$ & $X$ & $\bar{X}$ & $X$ & $X$ & $\bar{X}$ & $X$ & $X$ & $X$ \\
\hline $\begin{array}{l}\text { Discussion w/ } \\
\text { Health Care } \\
\text { Professional in } \\
\text { group }\end{array}$ & & & & & & $X$ & & \\
\hline $\begin{array}{l}\text { Written material } \\
\text { w/ discussion }\end{array}$ & & $X$ & & & & & & \\
\hline
\end{tabular}




\section{Project Implementation}

It is critical to success of the project that stakeholders are identified early and involved throughout the process (Melnyk \& Fineout-Overholt, 2011). The best evidence-based project cannot be successful without achieving actual implementation and that cannot be accomplished in a vacuum.

The population of interest is identified as residents in nursing homes that currently use the ISNP program. This criterion eliminates from this project residents who are not involved with the ISNP program in a nursing home. This was stipulated based on the organization implementing the protocol and is in alignment with the literature. The practice setting is defined by the population of interest-nursing home residents-which is the location that the ISNP provides medical care to the residents. Resources have been identified through the stakeholders and strong support has been secured for the project including expansion after the first quarter and the possibility of national implementation based on outcomes. Funding for the video and laptop batteries is supported by the ISNP program. The CNO has verified that the university IRB process is sufficient for the organization and no other approval is required. All applicable privacy regulations and long term care requirements apply as they do currently within advanced care planning and CPR discussions. No additional legislative oversight is incurred with the addition of the CPR video decision tool. Contracting for access to the CPR video has been completed with Dr.Volandes and the Nous Foundation, as well as the invoices have been submitted for payment.

Outcomes will be measured as the percentage of residents requesting CPR as documented in the EHR. This metric rolls up into the Clinical Indicator Reports quarterly 
and does not include individual resident names—only the facility name is provided for evaluating trends. The current metric is $36.7 \%$ of residents in the ISNP program have selected CPR. The protocol will be considered successful if the metric is lower than $36.7 \%$ for the program. Secondary outcomes could be a reduction in hospitalizations and a reduction in medical expenses. Those metrics are also impacted by many other variables and are indirect measurements. Therefore, the most direct measurement will be used to evaluate the outcome-the percentage of residents requesting CPR.

A 90 day timeline including a step by step implementation plan (Table 6—Project Implementation Timeline) has been developed to guide activities and ensure continued forward momentum. The target date for implementation is January 1, 2012. This will allow for clean data collection in the EHR and comparison between quarters as well as annual data if the project is continued. Meetings and discussions held with stakeholders in preparation for implementation will help to ensure a smooth roll out.

\section{Table 6: Project Implementation Timeline}

\begin{tabular}{|l|l|l|}
\hline \multicolumn{1}{|c|}{ October } & \multicolumn{1}{c|}{ Person Responsible } & \multicolumn{1}{c|}{ Status / Goal Date } \\
\hline Clarify project \& outcome & CNO & Completed \\
\hline Identify stakeholders & DNP student & Completed \\
\hline $\begin{array}{l}\text { Initiate discussions w/ } \\
\text { stakeholders }\end{array}$ & DNP student & Initiated and ongoing \\
\hline $\begin{array}{l}\text { Analyze facility CPR } \\
\text { metrics for }>50 \% \\
\text { wanting CPR }\end{array}$ & DNP student & Completed \\
\hline Identify target facilities & DNP student & Completed \\
\hline Confirm pricing w/ Nous & DNP student & Completed \\
\hline \multicolumn{1}{|c|}{ November } & Person Responsible & \multicolumn{1}{|c|}{ Status / Goal Date } \\
\hline $\begin{array}{l}\text { Provide timeline, project } \\
\text { proposal \& pricing to } \\
\text { preceptor }\end{array}$ & $\begin{array}{l}\text { Health Services Director } \\
\text { (HSD) }\end{array}$ & Completed \\
\hline $\begin{array}{l}\text { Decision on group or } \\
\text { individual method for } \\
\text { project }\end{array}$ & $\begin{array}{l}\text { HSD w/ CNO \& executive } \\
\text { stakeholders }\end{array}$ & $\begin{array}{l}\text { Individual NP-10.20.11 } \\
\text { decided }\end{array}$ \\
\hline Continue to interact w/ & HSD or designee & ongoing \\
\hline
\end{tabular}




\begin{tabular}{|c|c|c|}
\hline $\begin{array}{l}\text { shareholders to build } \\
\text { excitement }\end{array}$ & & \\
\hline $\begin{array}{l}\text { Plan \& execute meetings } \\
\text { w/ involved NPs and } \\
\text { facilities to provide details }\end{array}$ & HSD or designee & 12.15 .11 \\
\hline $\begin{array}{l}\text { Purchase extended } \\
\text { batteries if needed }\end{array}$ & HSD or designee & 11.30 .11 \\
\hline $\begin{array}{l}\text { Finalize subscription } \\
\text { payment w/ Nous for } \\
\text { CPR video }\end{array}$ & $\begin{array}{l}\text { HSD w/ Dr. Volandes \& } \\
\text { Executive Director }\end{array}$ & Submitted 10.31.11 \\
\hline December & Person Responsible & Status / Goal Date \\
\hline $\begin{array}{l}\text { Continue to interact w/ } \\
\text { shareholders to build } \\
\text { excitement }\end{array}$ & HSD or designee & ongoing \\
\hline $\begin{array}{l}\text { Verify access to CPR } \\
\text { video decision tool on NP } \\
\text { laptops }\end{array}$ & HSD \& NPS & 12.15 .11 \\
\hline $\begin{array}{l}\text { Verify link connectivity to } \\
\text { CPR video in facilities }\end{array}$ & HSD \& NPS & 12.15 .11 \\
\hline $\begin{array}{l}\text { Plan kick off event to } \\
\text { build excitement } w / N P s\end{array}$ & HSD or designee & 1.3 .12 \\
\hline $\begin{array}{l}\text { Schedule weekly } \\
\text { conference calls w/ NPs } \\
\text { to identify barriers or } \\
\text { snags with project roll out } \\
\text { initially; then re-evaluate } \\
\text { frequency of calls }\end{array}$ & HSD or designee & 12.15 .11 \\
\hline $\begin{array}{l}\text { Continue to provide } \\
\text { support and feedback } \\
\text { throughout project } 90 \\
\text { days }\end{array}$ & HSD or designee & 3.31 .12 \\
\hline $\begin{array}{l}\text { Analyze data and } \\
\text { compare before and after } \\
\text { intervention on \% CPR }\end{array}$ & HSD or designee & 4.15 .12 \\
\hline $\begin{array}{l}\text { Provide data analysis to } \\
\text { stakeholders }\end{array}$ & HSD or designee & 4.30 .12 \\
\hline
\end{tabular}

The EBP Implementation Plan for the CPR Video Decision Tool (Melnyk \& Fineout-Overholt, 2011) is detailed in Appendix $G$ to ensure all steps are planned. The budget has been previously outlined for implementation of the project including projected costs and potential expense reduction. 


\section{CPR Video Decision Tool Protocol}

Current evidence supports the integration of a CPR video decision tool into the advance care planning process which currently exists in the ISNP program between nursing home residents, their decision makers and the NP. The current advance care planning process includes discussion and documentation of the following components:

1. Decision making capacity —if that is the resident or identification of a surrogate decision maker including name and contact information;

2. Determination if a living will, advance directive or DNR exists and wishes contained in the document;

3. Goals of care-longevity, function or comfort;

4. Code status and intubation wishes;

5. Preferred place of death;

6. Hospice eligibility and if a referral was made. Integration of the CPR video into this discussion for residents who are undecided or who have chosen CPR will improve the alignment of resident care choices with care provided, increase understanding of the lack of effectiveness of CPR in nursing home residents due to underlying chronic illnesses and promote autonomy in decision making. The NP will make the decision when to integrate the CPR video into the discussion based on assessment of the conversation. In most cases the verbal discussion outlined above will occur followed by viewing of the CPR video. The CPR video is available through the Nous Foundation's website at www.acpdecisions.org or can be downloaded onto the laptop to avoid connectivity issues and is 2 minutes 33 seconds long. 


\section{Evaluation Plan}

Components to be evaluated in the implementation process include accessibility to the CPR video either through the website link or downloaded on to the NP's laptop. A weekly call will be scheduled during the first month to identify and resolve any issues that may not have been anticipated. The frequency of the call will be re-evaluated as the project implementation takes hold so the call does not become a burden.

The selection of CPR as opposed to do not attempt resuscitation (DNAR) or comfort care interventions is a true measure and not a surrogate measure. A surrogate measure is defined as using an intermediate outcome as a substitute end point measure (DiCenso, Guyatt, \& Ciliska, 2005, p 224). The metric for identifying the selection of CPR is a true measure and not a surrogate based on this definition.

The outcome measurement of selection of CPR versus DNAR as documented in the electronic health record is a reliable and valid measure. The outcome is a true measurement and not a surrogate end point, and is therefore valid (Dicenso, Guyatt \& Ciliska, 2005). Reliability indicates that the metric "will measure the same construct consistently every time" (Melnyk \& Fineout-Overholt, 2011, p. 232). Since, the metric is simply yes or no to CPR, it is reliable. The caveat is that in the absence of a DNAR order or absence of decision making capacity to select DNAR, the default is CPR. So, it is not always actively and consciously selected but may be the default if no decision maker can be identified to state otherwise. This is a significant point of opportunity-if health care professionals could determine that CPR is an intervention that is not appropriate in certain circumstances and therefore should not be attempted, the provision of CPR could be specifically directed toward appropriate patients. 
The outcome to be evaluated is the percentage of residents requesting CPR which is currently $36.7 \%$ in the ISNP program. It is anticipated that this percentage will decrease as a result of implementing the CPR video decision tool into the advance care planning process. The measurement will be monitored from the clinical indicator reports on a quarterly basis by nursing home. Eight nursing homes will be included in the initial implementation to resolve any unforeseen challenges. The project can be expanded to the 74 additional nursing homes in the ISNP program and stakeholders support national expansion if the projected outcomes are realized.

It is not anticipated that an evaluation of the nursing home settings is needed as the NPs already function in that environment and they do not need any additional supplies from the nursing home-the power, video and laptop are all supplied by the ISNP program and brought into the nursing home by the NP.

The clinical indicator report (Appendix $\mathrm{H}$ ) is available quarterly and will be analyzed following the first quarter of 2012 for the six facilities in which the project was implemented. Results will be disseminated to the NPs at the monthly staff meeting, senior leadership stakeholders at the quarterly business review meetings and to other stakeholders via meetings, conference calls or email updates. Application has been made to present the results at the May 2012 Ohio Health Care Association Conference for the nursing home industry and possibly the October 2012 Ohio Medical Director's Association Conference. Decisions to expand nationally would include WebEx presentations to site leadership across the country as well as to NP staff but that is not projected until 2013 based on outcome measurements. 
Project implementation will be evaluated through a survey at 30 days and 90 days post implementation with the NPs. Survey questions include comfort with using the CPR video tool, ease of use, ability of decision makers to access website or DVD to view the CPR video tool, and recommendations for future implementations (Appendix I).

A log will be maintained of the project implementation calls weekly in January; every other week in February and as needed thereafter. The log will be analyzed for missed barriers and improvements for future implementations (Appendix $\mathrm{J}$ ).

\section{Data Analysis}

Eight nursing homes and eight NPs were included in the initial implementation of the pilot video tool project. One facility closed mid-project and was excluded from the data analysis. The percentage of Evercare members requesting CPR in $4^{\text {th }}$ quarter 2011 was compared to the percentage of Evercare members requesting CPR after $1^{\text {st }}$ quarter 2012 as the video tool was implemented January 1, 2012. The mean percentage of patients requesting CPR in $4^{\text {th }}$ quarter was $51.125 \%$ with a standard deviation of .1474 (Table 7 ). The $4^{\text {th }}$ quarter median of the eight sites was .4795 with the lowest percentage .357 and the highest .708 . The $1^{\text {st }}$ quarter, after the CPR video tool was implemented, the mean percentage of patients requesting CPR was $45.77 \%$, with a standard deviation of .12122 . The $1^{\text {st }}$ quarter median .4500 with the lowest percentage at .286 and the highest at .645 . These data reflect the seven facilities that participated for the entire pilot.

The mean difference between $4^{\text {th }}$ quarter (Q4) and $1^{\text {st }}$ quarter (Q1) was .0550 or 5.5\% with the standard deviation Q4 to Q1 being .06075 (Table 7). The median difference was .0310 or $3.1 \%$ with the minimum change -.09 (indicating actually an 
increase in residents requesting CPR in one facility) and a maximum change of .08 with one facility showing no change between Q4 and Q1.

\begin{tabular}{|l|r|r|r|}
\hline & \multicolumn{1}{|c|}{ Statistics } \\
\hline $\mathrm{N} \quad$ Q4 & \multicolumn{1}{c|}{ Q1 } & \multicolumn{2}{|c|}{ diff } \\
\hline \multicolumn{1}{|c|}{ Missing } & 8 & 7 & 7 \\
Mean & 0 & 1 & 1 \\
Median & .51125 & .45557 & 0.06 \\
Std. Deviation & .47950 & .45000 & 0.03 \\
Minimum & .147437 & .121225 & .06075 \\
Maximum & .357 & .286 & -.09 \\
\hline
\end{tabular}

Table 7: Descriptive Statistics

A single sample t-test was used to determine if the $5.5 \%$ decrease in patients requesting CPR from Q4 to Q1 was significant.

Table 8: Tests of Between-Subjects Effects

Dependent Variable: diff

\begin{tabular}{|l|r|r|r|r|r|r|r|}
\hline Source & $\begin{array}{c}\text { Type III Sum of } \\
\text { Squares }\end{array}$ & df & Mean Square & F & Sig. & $\begin{array}{c}\text { Partial Eta } \\
\text { Squared }\end{array}$ & Observed Power \\
\hline Intercept & .007 & 1 & .007 & 1.823 & .226 & .233 & \\
Error & .022 & 6 & .004 & & & & \\
Total & .029 & 7 & & & & & \\
\hline
\end{tabular}

b. Computed using alpha $=.05$

The t-test indicates that the result is not significant as $p=.226$ which is greater than .05 .

The partial eta squared reflects the effect size and is small at .233. The observed power was .208 which is lower than an optimal power of .8 or greater.

Addition of the CPR video tool to the advance care planning discussions by the NPs did not make a significant difference to the number of residents requesting CPR $(p=.226)$ in the seven facilities piloted. One facility showed no change before and after and one facility with a new NP actually increased in the number of residents requesting 
CPR. Despite the lack of statistical significance, a 5.5\% reduction in residents selecting CPR with an equivalent reduction in hospitalizations would reduce medical expenses by $\$ 56,987$.

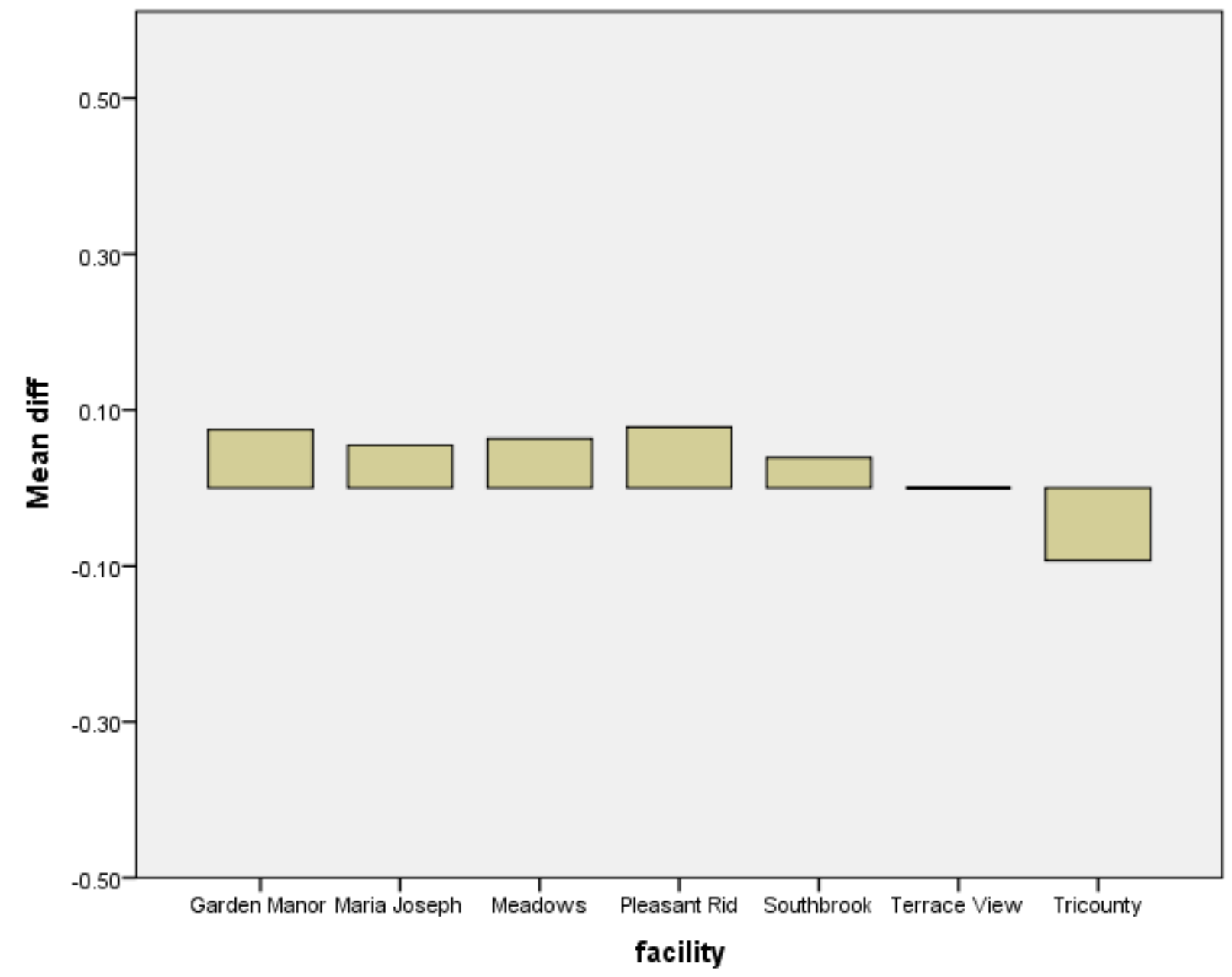

Figure 1: Difference in Residents Requesting CPR by Facility Q4 to Q1 Project implementation Analysis

A five question survey was completed by the participating NPs at 30 and 90 days post implementation to improve the process for future expansion of the CPR video tool project. A five point scale with 1 being strongly disagree and 5 being strongly agree was utilized for the first two questions of the survey. The eight NPs felt the initial preparation and education for implementation of the pilot project was acceptable with 
the range of responses $3-4$ and the mean response 3.375. Preparation and education was accomplished through a face to face educational session on either December 14 or 22 with follow up conference calls on January $3,10,17,24$ and February 28 . The second question focused on integration of the CPR video tool into advance care planning. The range of responses was 1-2 on the five point scale with a mean response of 1.25 . The video was very challenging for the NPs to use initially because of technological issues with Wi-Fi, DVD and downloading to laptop for use. It quickly became apparent that the population was also challenging as getting the patient and family to the facility to watch the video and have the discussion with the NP was difficult. The remaining questions were open-ended and focused on strategies to improve use of the CPR video tool. The NPs recommended using the video tool at admission when the family is already present at the facility or to plan a family night and do a group presentation. A recommendation to improve the initial implementation was to do a presentation to the nursing home management especially the DON and LSW. As noted by the NPs, challenges encountered during implementation of the pilot included: Lack of family involvement, lack of family response to scheduling a time to view the CPR video and discuss advance care plan options with the NP, technological challenges, and recommendation to use CPR video tool with patients prior to admission to the nursing home setting.

Additional recommendations obtained during the implementation conference calls included the administrative assistant sending copies of the DVD to families as requested by the NPs, and sharing the CPR video tool with the MDS nurse, LSW and DON as several NPs reported positive comments from nursing home staff after viewing. 
Software issues were numerous and included inability to get the video to load onto laptops, need for special approvals for additional software installations through the corporate office, sharepoint access to video, and need for obtaining files in several formats from Dr. Volandes.

\section{Conclusion}

The first day of the month, a nursing home resident enrolled in the ISNP program. The day after her enrollment, she suffered a cardiac arrest, was given CPR by the facility staff, and sent to the emergency department via 911 . She was 101 years old and died at the emergency room. That is not a dignified death and most individuals do not want to be the victim of such a situation. She was "benevolently assaulted" in compliance with her "request for CPR" or absence of an appropriate decision maker so she defaulted to CPR. Implementing this CPR Video Decision Tool Project may not have prevented her situation, but it has the potential to prevent many similar situations.

CPR is considered a standard of care and public misconceptions about the effectiveness of CPR are driven by television and lack of accurate information (Adams \& Snedden, 2006; van Mil et al., 2000). In reality, CPR on nursing home residents has consistently demonstrated poor outcomes with less than a $5 \%$ survival rate and several studies showing no survivors (American Medical Directors Association, January 30, 2011). Health care expenditures are disproportionate near death and end of life treatments drive $78 \%$ of the costs into the final 30 days of life compared to the prior year (Yu, 2008). Implementing the CPR video decision tool into the advance care planning discussions, already a component of the ISNP program, did not demonstrate a significant change $(p=.226)$ although a reduction of $5.5 \%$ in the number of residents 
requesting CPR resulted from the implementation of the CPR video tool. Despite the lack of statistical significance, a 5.5\% reduction in residents selecting CPR with an equivalent reduction in hospitalizations would reduce medical expenses by $\$ 56,987$ over 90 days. Artifacts included a new NP in a facility that subsequently showed an increase in the percentage of patients requesting CPR between Q4 and Q1, as well as one facility that demonstrated no change.

Use of the CPR video tool promotes end of life care in accordance with the resident's wishes and demonstrates the potential to reduce health care costs at the end of life. All of this, while offering a dignified and respectful death as opposed to "modus exitus" defined by failure to survive CPR (Gordon, 2003). Future areas of study include use of the CPR video tool for family educational events at the nursing home to facilitate family involvement and avoid scheduling issues identified by the NPs in this study and outreach to potential residents prior to admission perhaps through senior center educational events or assisted living sites. 


\section{References}

Adams, D. \& Snedden, D. (2006). How misconceptions among elderly patients regarding survival outcomes of inpatient cardiopulmonary resuscitation affect donot-resuscitate orders. JAOA: Journal of the American Osteopathic Association, 106(7), 402-4.

American Medical Association: Policy on provision of life-sustaining medical treatment (2009). Printed 1.30.11 http://www.ama-assn.org/ama/pub/physicianresources/medical-ethics/about-ethics-group/

American Medical Directors Association: White paper on surrogate decision-making and advance care planning in long-term care. Printed 1.30.11 http://www.amda.com/governance/whitepapers/surrogate/clinical.cfm

Anderson, J.E., Sikorski, I., \& Finucane, T.E. (2006). Advance care planning by or on behalf of peritoneal dialysis patients in long-term care. American Journal of Kidney Diseases, 48 (1), 122-127. doi: 10.1053/j.ajkd.2006.03.041

Aw, D., Hayhoe, B., Smajdor, A., Bowker, L.K., Conroy, S.P. \& Myint, P.K. (2011). Advance care planning and the older patient. Quarterly Journal of Medicine. Advance online publication. doi:10.1093/qjmed/hcr209

Barnes, K., Jones, L., Tookman, A., \& King, M. (2007). Acceptability of an advance care planning interview schedule: A focus group study. Palliative Medicine, 21, 23-28. doi: $10.1177 / 026926306073638$ 
Cherniack, E. (2002). Increasing use of DNR orders in the elderly worldwide: whose choice is it? Journal of Medical Ethics, 28(5), 303-7.

Dicenso, A., Guyatt, G. \& Ciliska, D. (2005). Evidence-based nursing: A guide to clinical practice. St. Louis, MO: Elsevier Mosby.

Dipko, LR, Xavier, K and Kohlwes, RJ., (2003). "Advance directive group education in a VA outpatient clinic." Social Work in Health Care, 38 (2), 93-106.

Duke, G, Yarbrough, S, and Pang, K. (2009). The Patient Self-Determination Act: 20 Years Revisited. Journal of Nursing Law, 13(4) 114-122

Frank, C., Pichora, D., Suurdt, J. \& Heyland, D. (2010). Development and use of a decision aid for communication with hospitalized patients about cardiopulmonary resuscitation preference. Patient Education and Counseling 79 (2010), 130-133. doi: 10.1016/j.pec.2009.08.002

Fried, T.R., Redding, C.A., Robbins, M.L., Paiva, A., O'Leary, J.R., \& lannone, L. (2010). Stages of change for the component behaviors of advance care planning. Journal of the American Geriatric Society, 58, 2329-2336. doi: 10.1111/j.1532-5415.2010.03184.x

Gordon, M. (2003). CPR in long-term care: mythical benefits or necessary ritual? Annals of Long-Term Care, 11(4), 41-49.

Hirschman, K.B., Abbott, K.M., Hanlon, A.L., Bettger, J.P. \& Naylor, M.D. (2012). What factors are associated with having an advance directive among older adults who 
are new to long term care services? Journal of American Medical Directors, 13, 82e7-82e11.

Janis, I.L. \& Mann, L. (1977). Decision Making: A Psychological Analysis of Conflict, Choice, and Commitment. New York: The Free Press.

Jezewski, M.A. \& Meeker, M.A. (2005). Constituting advance directives from the perspective of people with chronic illnesses. Journal of Hospice and Palliative Nursing, 7(6), 319-327.

Johnson, J.M. \& Nelson, A. (2008). The acceptability of an information leaflet explaining cardiopulmonary resuscitation policy in the hospice setting: $\mathrm{A}$ qualitative study exploring patients' views. Palliative Medicine (22), 647-652.

Laakkonen, M., Pitkala, K., Strandberg, T., Berglind, S. \& Tilvis, R. (2005). Older people's reasoning for resuscitation preferences and their role in the decisionmaking process. Resuscitation, 65(2), 165-71. doi:10.1016/j.resuscitation.2004.11.016

Lazaruk, T. (2006). The CPR Question. Canadian Nurse, 102(2), 22-24.

Lee, K.H., Angus, D.C. \& Abramson, N.S. (1996). Cardiopulmonary resuscitation: what cost to cheat death? Critical Care Medicine, 12(12), 2046-2052.

Levi, B.H., Heverley, S.R. \& Green, M.J. (2011). Accuracy of a decision aid for advance care planning: simulated end-of-Life decision making. The Journal of Clinical Ethics, 22(3), 223-238. 
Levy, C., Morris, M. \& Kramer, A. (2008). Improving end-of-life outcomes in nursing homes by targeting residents at high-risk of mortality for palliative care: program description and evaluation. Journal of Palliative Medicine, 11(2), 217-25. doi:10.1089/jpm.2007.0147

Lopez, R.P. (2009). Decision-making for acutely ill nursing home residents: nurses in the middle. Journal of Advanced Nursing, (65) 5, 1001-1009.

Mallery, L., Jubbard, R.E. Moorhouse, P., Koller, K., \& Eeles, E.M.P. (2011). Specialist physician approaches in discussing cardiopulmonary resuscitation for frail older adults: A qualitative study. Journal of Palliative Care, 27(1), 12-19.

Matzo, M., Hijjazi, K., \& Outwater, M. (2008). Older Oklahomans' knowledge, attitudes, and behaviors related to advance directives. Journal of Gerontological Nursing, 34(2), 21-26.

McBee, L., Burack, O.R., Carter, J.M. \& Chichin, E.R. (2000). Discussing DNR / CPR Preferences in the nursing home: A key component of advance care planning. ABCD Exchange, Nov-Dec., www.abcd-caring.org

Melnyk, B.M. \& Fineout-Overholt, E. (2011). Evidence-based practice in nursing \&healthcare: A guide to best practice. Philadelphia: Wolters Kluwer / Lippincott Williams \& Wilkins. 
Messinger-Rapport, B. \& Kamel, H. (2005). Predictors of do not resuscitate orders in the nursing home. Journal of the American Medical Directors Association, 6(1), 1821. doi:10.1016/j.jamda.2004.12.006

Molloy, D.W., Guyatt, G.H., Russo, R., Goeree, R., O’Brien, B.J., Bedard, M., Willan, A.,Watson, J., Patterson, C., Harrison, C., Standish, T., Strang, D., Darzins, P.J., Smith, S., \& Dubois, S. (2000). Systematic implementation of an advance directive program in nursing homes. Journal of the American Medical Association, 283 (11), 1437-1444.

National Hospice and Palliative Care Organization (2012). Annual report, facts and figures: Hospice care in America. Medical Ethics Advisor, 3(1), 31.

Nicholas, L.H., Langa, K.M., Iwashyna, T.J., \& Weir, D.R. (2011). Regional variation in the association between advance directives and end-of-life medicare expenditures. Journal of the American Medical Association, 306(13), 14471453.

Nous Foundation (Dr. Volandes, producer). (2010). Generic CPR Video (video link). Available from www.acpdecisions.org

Ouslander, J.G. \& Berenson, R.A. (2011). Reducing unnecessary hospitalization of nursing home residents. The New England Journal of Medicine, 365(13) 11651167. 
Ramsaroop, S.D., Reid, M.C., \& Adelman, R.D. (2007). Completing an advance directive in the primary care setting: What do we need for success? Journal of the American Geriatric Society, (55), 277-283.

Rosswurm, M.A., \& Larrabee, J.H. (1999). A model for change in evidence-based practice. Journal of Nursing Scholarship, 31(4), 317-322.

Silveira, M.J., Kim, S.Y.H., \& Langa, K.M. (2010). Advance directives and outcomes of surrogate decision making before death. The New England Journal of Medicine, $362(13), 1211-1218$.

Simon-Lorda, P., Barrio-Cantalejo, I.M., Garcia-Gutierrez, J.F., Tamayo-Velazquez, M.I., Villegas-Portero, R., Higueras-Callejon, C., \& Martinez-Pecino, F. (2008). Interventions for promoting the use of advance directives for end-of-life decisions in adults (protocol). The Cochrane Library, (4).

Storch, J.L. (2006). Commentary. Canadian Nurse, 102 (2), 23-24.

Sudore, R.L., \& Fried, T.R. (2010). Redefining the "planning" in advance care planning: Preparing for end-of-life decision making. Annals of Internal Medicine, 153 (4), 256-261.

Thorevska, N., Tilluckdharry, L., Tickoo, S., Havasi, A., Amoateng-Adjepong, Y. \& Manthous, C. A. (2005). Patients' understanding of advance directives and cardiopulmonary resuscitation. Journal of Critical Care, 20(1), 26-34. doi:10.1016/j.jcrc.2004.11.002 
van Mil, A.H.M., van Klink, R.C.J., Huntjens, C., Westendorp, R.G.J., Stiggelbout,A.M., Meinders, A.E., \& Lagaay, A.M. (2000). Cardiopulmonary resuscitation preferences in Dutch community-dwelling and hospitalized elderly people: An interaction between gender and quality of life. Medical Decision Making, 2000 (20), 423-429. doi:10.1177/0272989x0002000406

Volandes, A.E., Barry, M.J., Chang, Y. \& Paasche-Oslow, M.K. (2010). Improving decision making at the end of life with video images. Medical Decision Making, 30(1), 29-34. doi:10.1177/0272989X09341587

Volandes, A.E., Ferguson, L.A., Davis, A.D., Jull, N.C., Green, M.J., Chang, Y., Deep, K. \& Paasche-Orlow, M.K. (2011). Assessing end-of-life preferences for advanced dementia in rural patients using an educational video: A randomized controlled trial. Journal of Palliative Medicine 14 (2), 8 pg. doi: 10.1089/jpm.2010.0299

Volandes, A.E., Levin, T.T., Slovin, S., Carvajal, R.D., O'Reilly, E.M., Keohan, M.L.,...Noy, A. (2012). Augmenting advance care planning in poor prognosis cancer with a video decision aid: A preintervention - postintervention study. Cancer, 1-8. doi: 10.1002/cncr.27423.

Volandes, A.E., Mitchell, S.L., Gillick, M.R., Chang, Y., \& Paasche-Oslow, M.K. (2009). Using video images to improve the accuracy of surrogate decision-making: A randomized controlled trial. The Journal of the American Medical Directors Association (10), 575-580. doi:10.1016/j.jamda.2009.05.006 
Volandes, A.E., Paasche-Orlow, M.K., Barry, M.J., Gillick, M.R., Minaker, K.L., Chang, Y., Cook, E.F., Abbo, E.D., El-Jawahri, A., \& Mitchell, S.L. (2009). Video decision support tool for advance care planning in dementia: randomized controlled trial. British Medical Journal, 3(38). Doi:10.1136/bmj.b2159

Yu, W. (2008). End of life care: medical treatments and costs by age, race and region. Health Services Research and Development study IIR 02-189. http://www.hsrd.research.va.gov/research/abstracts/IIR 02-189.htm.

Zhang, B., Wright, A.A., Juskamp, J.A., Nilsson, M.E., Maciejewski, M.L., Earle, C.C.,Block, S.D., Maciejewski, P.K. \& Prigerson, H.G. (2009). Health care costs in the last week of life: Associations with end-of-life conversations. Archives of Internal Medicine, 169 (5), 480-488. 


\section{Appendix A}

\section{Literature Search Table}

\begin{tabular}{|c|c|c|c|c|c|}
\hline $\begin{array}{l}\text { Date of } \\
\text { Search }\end{array}$ & Keyword Used & $\begin{array}{c}\text { Database/Source } \\
\text { Used }\end{array}$ & Listed & $\begin{array}{l}\text { \# of Hits } \\
\text { Reviewed }\end{array}$ & Used \\
\hline $01 / 23 / 11$ & $\begin{array}{l}\text { CPR and } \\
\text { decision aid }\end{array}$ & CINAHL & 2 & 1 & 1 \\
\hline $01 / 23 / 11$ & $\begin{array}{l}\text { Decision tool } \\
\text { and older adult } \\
\text { or geriatric }\end{array}$ & CINAHL & 0 & 0 & 0 \\
\hline $01 / 23 / 11$ & CPR & CINAHL & 2107 & 0 & Too large \\
\hline $01 / 23 / 11$ & $\begin{array}{l}\text { CPR and age } \\
\text { group }\end{array}$ & CINAHL & 0 & 0 & 0 \\
\hline $01 / 23 / 11$ & CPR and elder* & $\begin{array}{l}\text { CINAHL-see } \\
\text { table } 2 \text { below }\end{array}$ & 21 & 21 & 12 \\
\hline $01 / 23 / 11$ & Decision aid & CINAHL & 203 & 0 & Too large \\
\hline $01 / 23 / 11$ & $\begin{array}{l}\text { Decision aid and } \\
\text { elder* }\end{array}$ & $\begin{array}{l}\text { CINAHL-see } \\
\text { table } 2 \text { below }\end{array}$ & 2 & 2 & 0 \\
\hline $01 / 23 / 11$ & $\begin{array}{l}\text { Decision aid and } \\
\text { code status }\end{array}$ & CINAHL & 0 & 0 & 0 \\
\hline $02 / 01 / 11$ & $\begin{array}{l}\text { End of life and } \\
\text { CPR and } \\
\text { decision aid }\end{array}$ & CINAHL & 0 & 0 & 0 \\
\hline $02 / 01 / 11$ & $\begin{array}{l}\text { End of life and } \\
\text { decision aid }\end{array}$ & CINAHL & 3 & 3 & 2 \\
\hline $03 / 27 / 11$ & $\begin{array}{l}\text { Advance } \\
\text { directive* }^{*}\end{array}$ & CINAHL & 74 & 31 & 5 \\
\hline $10 / 11 / 11$ & Updated search & CINAHL & 27 & 27 & 12 \\
\hline $07 / 30 / 12$ & Updated search & CINAHL & 93 & 14 & 5 \\
\hline
\end{tabular}




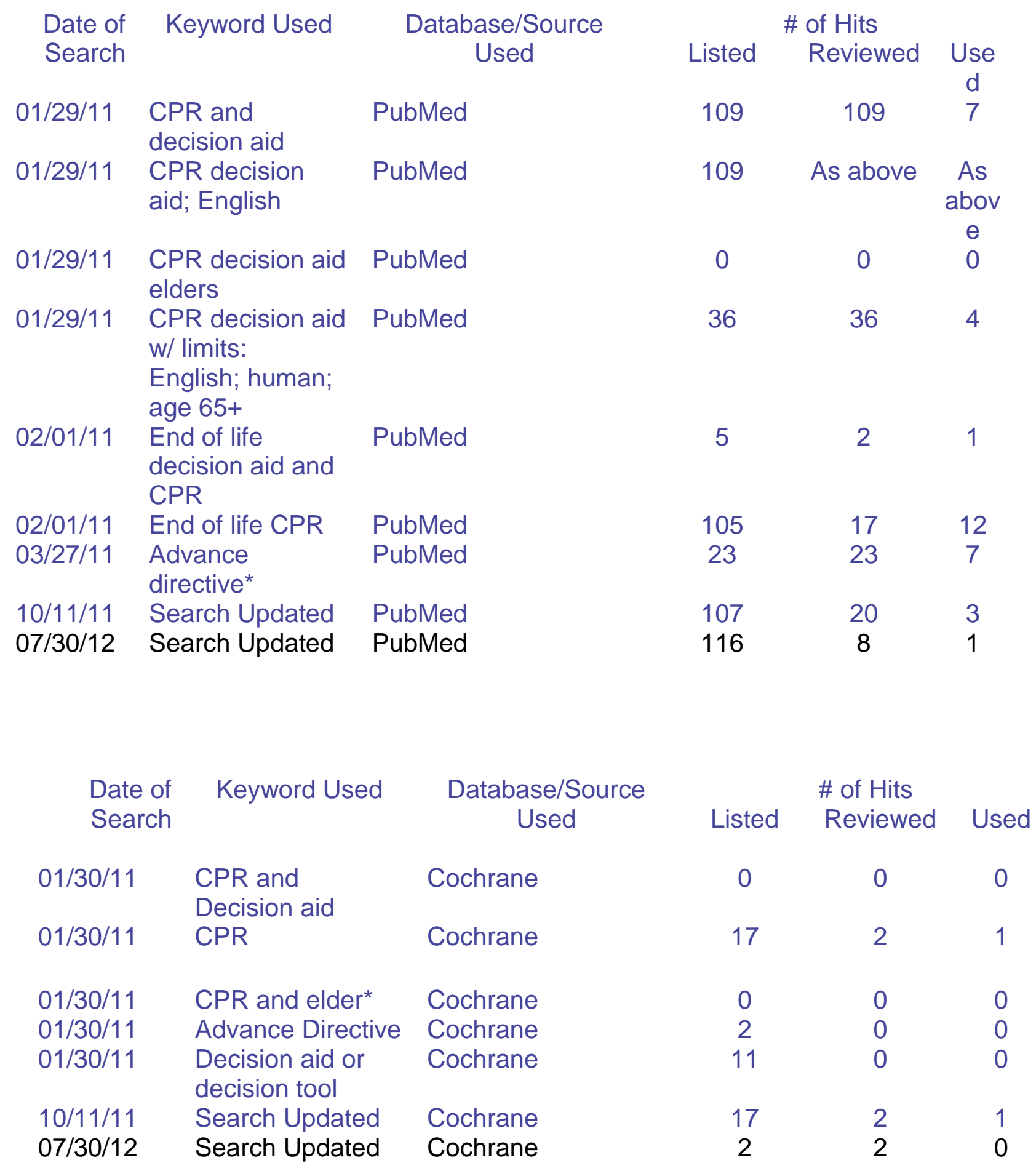




\section{Appendix B}

\section{Characteristics of Studies Included and Excluded}

Title

9 studies excluded from CPR and elder ${ }^{*}$ CINAHL search due to: age of study (1993), focus on nurses' attitudes, language, elder as provider of CPR, pulmonary rehab not CPR.

Comparison of medical and nursing attitudes to resuscitation and patient autonomy between a British and an American teaching hospital

Safety and efficacy of pulmonary rehabilitation in elderly females with chronic obstructive pulmonary disease: a pilot report. Intentions to use an automated external defibrillator during a cardiac emergency among a group of seniors trained in its operation

Attitudinal patterns determining decision-making in severely ill elderly patients: a cross-cultural comparison between nurses from Sweden and Germany. Reducing unnecessary hospitalizations of nursing home residents

Effect of age on prehospital cardiac resuscitation outcome... presented in part at the Society for Academic Emergency Medicine Annual Meeting, San Francisco, CA, May 1993, and the 8th World Congress of Emergency and Disaster Medicine, Stockholm, Sweden A randomized trial of the capability of elderly lay persons
Author (year)

Mello M; Jenkinson C; (1998)

Arena, R., Greenspan, N, Tevald, M., and Haas, J. (2003) Meischke, H.W., Rea T.D., Eisenberg, M.S., and Rowe, S.M. (2002)

Richter, J., and Eisemann, M.R. (2001)

Ouslander, J, and Berenson, R.A. (2011)

Wuerz RC; Holliman $\mathrm{CJ}$; Meador SA; Swope GE; Balogh R (1995)
Included and Rationale or Excluded and Rationale

Details outlined below

Excluded: focus on nursing attitudes not decision makers

Excluded: focus on pulmonary rehab not CPR

Excluded: focus on elders as providers of CPR

Excluded: focus on nurses attitudes not decision makers

Included: treating in place; CPR status in nursing home residents

Excluded: age of study was 1993
Neset A; Birkenes Excluded: focus on elders as TS; Myklebust $\mathrm{H}$; providers of CPR 
to perform chest compression

only CPR versus standard 30:2 CPR.

Estimating cost-effectiveness of mass cardiopulmonary resuscitation training strategies to improve survival from cardiac arrest in private locations. Plasma adiponectin plays an important role in improving insulin resistance with glimepiride in elderly type 2 diabetic subjects

Attitudes of Canadian radiation
oncologists towards post-
lumpectomy radiotherapy for
elderly women with stage I
hormone-responsive breast
cancer.
Vulnerable older people in the
community: relationship between
the Vulnerable Elders Survey and
health service use.

End-of-life decision making is more than rational.

Long term survival and costs per life year gained after out-ofhospital cardiac arrest

How misconceptions among elderly patients regarding survival outcomes of inpatient cardiopulmonary resuscitation affect do-not-resuscitate orders

Increasing use of DNR orders in the elderly worldwide: whose
Mykletun RJ; Odegaard S;

Kramer-Johansen

$\mathrm{J} ;(2010)$

Swor, R., and Excluded: focus on training of Compton, S.

(2004)

Tsunekawa T; Hayashi T; Suzuki Y; Matsui-Hirai H;

Kano H; Fukatsu

A; Nomura N; Miyazaki A; Iguchi A; (2003).

Warner E; Chow Excluded: unrelated to topic E; Fairchild A;

Franssen E;

Paszat L;

Szumacher E (2010)

McGee HM;

O'Hanlon A;

Barker M; Hickey

A; Montgomery A;

Conroy R; O'Neill

D (2008).

Eliott, JA, and

Olver, IN

Naess AC, Steen

PA (2004)

Adams, D. \& Snedden, D. (2006)

Cherniack, E. (2002).
CPR providers

Excluded: focus on diabetes in elders

Excluded: unrelated to topic

Excluded: focus on general method of decision making for surrogates

Excluded: Study in Norway and costs not reflective of US costs; subjects also described as CPR w/ spontaneous circulation and community dwelling elders Included: CPR outcomes impact on decisions 
choice is it?

Use of video to facilitate end-oflife discussions with patients with cancer: a randomized controlled trial.

Older people's reasoning for resuscitation preferences and their role in the decision-making process

Improving end-of-life outcomes in nursing homes by targeting residents at high-risk of mortality for palliative care: program description and evaluation Predictors of do not resuscitate orders in the nursing home

A decision aid for long-term tube feeding in cognitively impaired older persons

Patients' understanding of advance directives and cardiopulmonary resuscitation

Dilemmas in decision-making about resuscitation-a focus group study of older people.
El-Jawahri, A.,

Podgurski, L.,

Eichler, A.,

Plotkin, S., Temel,

J., Mitchell, S., ,...Volandes, A.

(2010).

Laakkonen, M., Included: study related to

Pitkala, K.,

Strandberg, T.,

Berglind, S.,

, \& Tilvis, R.

(2005).

Levy, C., Morris, Included: study focus was on

M., , \& Kramer, A. providing information to enable (2008).

Messinger-

Rapport, B., , \& Kamel, $\mathrm{H}$. (2005).

Mitchell SL;Tetroe Included: use of decision tool $\mathrm{J}$;O'Connor AM. (2001).

Thorevska, N., Tilluckdharry, L.,

Tickoo, S., Havasi, A., AmoatengAdjepong, Y., , \& Manthous, C.

A. (2005).

Vandrevala, T., Included: focus on CPR Hampson, S. E., decision making in older Daly, T., Arber, adults-not nursing home S., , \& Thomas, H. residents but may be able to (2006).
Included: study focus on nursing home residents and decision making for DNR in nursing home population although for other intervention; could extrapolate to CPR decision making Included: decision making regarding $\mathrm{CPR}$ extrapolate to similar population; UK
Systematic Implementation of an Advance
Molloy, et al JAMA, March 15,
Included: focus includes Advance Directives which 
Directive Program in Nursing Homes

A Randomized Controlled Trial Improving decision making at the end of life with video images.

Deciding About Cardiopulmonary Resuscitation

The Contributions of Decision

Analysis

Improving Decision Making at the End

of Life With Video Images

Assessing End-of-Life

Preferences for Advanced

Dementia

in Rural Patients Using an

Educational Video:

A Randomized Controlled Trial

The acceptability of an

information leaflet explaining

cardiopulmonary resuscitation

policy in the hospice setting:

a qualitative study exploring

patients' views

A framework for making advance

decisions on

resuscitation

Deciding about Cardio

Pulmonary Resuscitation

Advance Directives and Outcomes of Surrogate Decision Making Before Death
2000-Vol 283, included CPR decisions

No. 11

Volandes

AE;Barry

MJ;Chang

Y;Paasche-Orlow

MK. (2010).

Sorum (1995)

Angelo E.

Volandes, Michael

J. Barry, Yuchiao

Chang,

Michael K.

Paasche-Orlow, (2010)

Volandes, et al. Included: focus of study (2011)

Included: focus of study

closely aligned with my study

question

Included: study most closely question meet criteria

closely aligned with my study aligned with focus of my study

Excluded: age of study did not question

Johnson, H.M, et al (2008)

Regnard, C. \& Randall, F., (2005)

Paul C Sorum (1995)

Silveira, MJ, Kim, $\mathrm{SYH}$, Langa, KM (2010)
Included: decision tool used for CPR although setting is hospice

Included: study in England but focus end of life, CPR and decision making Excluded: age of publication and focus was decision analysis theory Included: prevalence of decision making needed; prevalence of lack of capacity; $\mathrm{AD}$ associated $\mathrm{w} /$ care alignment $\mathrm{w} /$ preference

Included: useful expert opinion-not research study
Advance Care Planning: Beyond Messingerthe Living Will
Rapport, B, 
Redefining the "Planning" in

Advance Care Planning:

Preparing for End-of-Life

Decision Making

Completing an Advance Directive in the Primary Care Setting: What Do We Need for Success?

Interventions for promoting the use of advance directives for end-of-life decisions in adults (Protocol)

Health Care Costs in the Last Week of Life

Older Oklahomans' Knowledge, Attitudes, and Behaviors Related to Advance Directives

Acceptability of an Advance care planning interview schedule: A focus group study

Stages of Change for the Component Behaviors of
Baum, EE, \&Smith, ML

(2009)

Sudore, RL, \& Included: synthesis of

Fried, TR (2010) literature w/ suggested alternative; ACP should focus on prep for in-the-moment decision making $w /$ surrogate vs. outcome of living will or $A D$

Ramsaroop, SD, Reid, MC, \& Adelman, RD (2007)

Ref list Simon-Lorda, $\mathrm{P}$, Barrio-Cantalejo, IM, GarciaGutierrez, JF, TamayoVelazuez,MI, Villegas-Portero, R, HiguerasCallejon, C, \& Martinez-Pecino, $\mathrm{F}$ (2008)

Zhang, Wright, Juskamp, Nilsson, Maciejewski, Earle, Block, Maciejewski \& Prigerson (2009) Matzo, M, Hijjazi, $\mathrm{K}$, \& Outwater, $\mathrm{M}$ (2008)

Barnes, $\mathrm{K}$, Jones, L, Tookman, A, \& King, M (2007)

Fried, TR, Redding, CA, Included: Meta analysis of 18 studies-most successful w/ direct pt interactions over multiple visits; written materials only ineffective for $A D$ w/o interaction / counseling Included: No conclusion-plan for analysis

Included: Changes in medical expenses for last week of life based on self-reported discussions $\mathrm{w} /$ physician on EOL decisions

Included: random sample phone survey; quantitative; $\mathrm{N}=804$; > $65 \mathrm{yr}=56.5 \%$ had $\mathrm{AD}$; $>18 \mathrm{yr}=27.3 \%$ had $\mathrm{AD} ; 76 \%$ "not gotten around to it" Included: Qualitative focus group study; timing of discussion imperative and will influence effect; adv decisions to refuse tx not focus but 1 component of EOL discussion; UK; self-selected sample Included: Observational cohort study; qualitative; develop 
Advance Care Planning

Advance Care Planning by or on Behalf of Peritoneal Dialysis Patients in LTC

Constituting Advance Directives from the Perspective of People w/ Chronic Illness

Patient Preferences in Instructional Advance Directives

Specialist physician approaches to discussing cardiopulmonary resuscitation for frail older adults: A qualitative study

Augmenting Advance Care Planning in poor prognosis cancer patients with video decision aid Patients snub end of life planning

Advance care planning and the older patient

Advance directives and end of life preferences

Advance directive discussion: Lost in translation
Robbins, ML, stages-of-change measures for Paiva, A, O'Leary, ACP-measure characteristics $\mathrm{JR}$, \& lannone, $\mathrm{L}$ of engagement; factors assoc (2010) $\mathrm{w} /$ readiness

Anderson, JE, Sikorski, I, \& Finucane, TE (2006)

Jezewki, MA, \& Meeker, MA (2005)

Abbo, ED, Sobotka, A, \& Meltzer, DO (2008)

Mallery, Hubbard, Moorhouse, Koller \& Eeles (2011)

Volandes et al (2012) Included: Retrospective chart review; $n=109$; 108 had ACP; compliance $\mathrm{w} /$ plan was limited; DNH order not assoc w/ likelihood of hosp; ACP not decisive in determining interventions during acute illness

Included: Qualitative, meaning of ADs to them, attitudes \& exp w/ ADs; perceived need for AD; 23 individual interviews \& 9 focus groups; total $n=76$; recruited from 16 support groups rep 10 chronic illnesses Included: test a modified AD $\mathrm{w} /$ limited life sustaining therapy for critical illness \& adv dementia over traditional $A D$ form; Convenience sample $n=72 ; 86 \%$ preferred modified AD over traditional form;

Qualitative study of 28

physician interviews on content of CPR discussion

Included: Pre/post intervention study using video decision aid; $\mathrm{n}=80$

Medical Ethics Advisor (2012) Aw et al (2012)

Included: California survey

Included: Review of current literature on advance directives and use

Chu et al (2011)

Fischer et al (2012)
Excluded: population in Hong Kong - different cultural values Excluded: focus on cultural disparities in formulating advance directives in community elders; not CPR decisions; not nursing home 
Factors associated with advance directives when new to long term care POLST

Accuracy of decision aide for advance care planning: Simulated end of life care planning Uncertainty in decision making

Advance directives in workplace

Regional variation in association with advance directives and end of life medical expenditures

Knowledge of nurses in completing advance directives
Hirschman, $\mathrm{K}$ et al Included: nursing home (2012)

Hammes, B et al (2012)

Levi, Heverley \&

Green (Fall 2011)

Lopez \& Guarino (2011)

Marchina (2011)

Nicholas, Langa, Iwashyna \& Weir (2011)

Ryan \& Jezewski (2012) population; predictors of advance directives

Excluded: retrospective chart review on alignment of POLST orders with actual end of life treatment Included: computer generated tool with interactive decision aid

Excluded: investigated caregiver uncertainty in end of life decision making Excluded: population of healthy adults working Included: retrospective observational study investigating costs of end of life care and variables

Excluded: population focus on $\mathrm{RNs}$ in ER, oncology \& ICU 


\section{Appendix C: Organizational Culture \& Readiness for System-Wide Integration of Evidence-based Practice Survey}

\begin{tabular}{|c|c|c|c|c|c|}
\hline Item & $\begin{array}{l}\text { None } \\
\text { at all }\end{array}$ & A Little & $\begin{array}{c}\text { Somewh } \\
\text { at }\end{array}$ & $\begin{array}{c}\text { Moder } \\
\text { ately }\end{array}$ & $\begin{array}{l}\text { Very } \\
\text { Much }\end{array}$ \\
\hline $\begin{array}{l}\text { To what extent is EBP clearly described as } \\
\text { central to the mission \& philosophy of your } \\
\text { institution? }\end{array}$ & 1 & 2 & 3 & 4 & 5 \\
\hline $\begin{array}{l}\text { To what extent do you believe EBP is } \\
\text { practiced at your institution? }\end{array}$ & 1 & 2 & 3 & 4 & 5 \\
\hline $\begin{array}{l}\text { To what extent is the nursing staff with whom } \\
\text { you work committed to EBP? }\end{array}$ & 1 & 2 & 3 & 4 & 5 \\
\hline $\begin{array}{l}\text { To what extent is the physician staff with } \\
\text { whom you work committed to EBP? }\end{array}$ & 1 & 2 & 3 & 4 & 5 \\
\hline $\begin{array}{l}\text { To what extent are there administrators } \\
\text { within your organization committed to EBP? } \\
\text { (resources planned, support, time for EBP?) }\end{array}$ & 1 & 2 & 3 & 4 & 5 \\
\hline $\begin{array}{l}\text { In your organization, is there a critical mass } \\
\text { of nurses with strong EBP knowledge and } \\
\text { skills? }\end{array}$ & 1 & 2 & 3 & 4 & 5 \\
\hline $\begin{array}{l}\text { To what extent are there nurse scientists } \\
\text { (doctorally prepared researchers) in your } \\
\text { organization to assist in generalization of } \\
\text { evidence when it does not exist? }\end{array}$ & 1 & 2 & 3 & 4 & 5 \\
\hline $\begin{array}{l}\text { To what extent are there Advanced Practice } \\
\text { Nurses who are EBP mentors for staff nurses } \\
\text { as well as other APNs? }\end{array}$ & 1 & 2 & 3 & 4 & 5 \\
\hline $\begin{array}{l}\text { To what extent do practitioners model EBP in } \\
\text { their clinical settings? }\end{array}$ & 1 & 2 & 3 & 4 & 5 \\
\hline $\begin{array}{l}\text { To what extent do staff nurses have access } \\
\text { to quality computers and access to electronic } \\
\text { databases for searching for evidence? }\end{array}$ & 1 & 2 & 3 & 4 & 5 \\
\hline $\begin{array}{l}\text { To what extend do staff nurses have } \\
\text { proficient computer skills? }\end{array}$ & 1 & 2 & 3 & 4 & 5 \\
\hline $\begin{array}{l}\text { To what extent do librarians within your } \\
\text { organization have EBP knowledge \& skills? }\end{array}$ & 1 & 2 & 3 & 4 & 5 \\
\hline $\begin{array}{l}\text { To what extent are librarians used to search } \\
\text { for evidence? }\end{array}$ & 1 & 2 & 3 & 4 & 5 \\
\hline $\begin{array}{l}\text { To what extent are fiscal resources used to } \\
\text { support EBP education, conferences, } \\
\text { workshops, paid time for EBP process, } \\
\text { mentors }\end{array}$ & 1 & 2 & 3 & 4 & 5 \\
\hline $\begin{array}{lc}\text { To what extent are there EBP champions? } \\
\text { Administrators } & 5 \\
\text { Physicians } & 5 \\
\text { Nurse Educators } & 5 \\
\text { APNs } & 4 \\
\text { Staff nurses } & 4\end{array}$ & 1 & 2 & 3 & 4 & 5 \\
\hline $\begin{array}{l}\text { To what extent is measuring and sharing of } \\
\text { outcomes part of the climate of the } \\
\text { organization? }\end{array}$ & 1 & 2 & 3 & 4 & 5 \\
\hline Item & None & $25 \%$ & $50 \%$ & $75 \%$ & $100 \%$ \\
\hline
\end{tabular}




\begin{tabular}{|c|c|c|c|c|c|}
\hline $\begin{array}{lc}\text { To what extent are decisions generated from: } \\
\text { Direct care providers? } & 4 \\
\text { Upper administration? } & 3 \\
\text { Physician or other health care provider } \\
\text { group? }\end{array}$ & 1 & 2 & 3 & 4 & 5 \\
\hline Item & $\begin{array}{l}\text { Not } \\
\text { ready }\end{array}$ & $\begin{array}{l}\text { Getting } \\
\text { ready }\end{array}$ & $\begin{array}{c}\text { Been } \\
\text { ready but } \\
\text { not } \\
\text { acting }\end{array}$ & $\begin{array}{l}\text { Ready } \\
\text { to Go }\end{array}$ & $\begin{array}{l}\text { Past } \\
\text { Ready } \\
\text { and on } \\
\text { to } \\
\text { action }\end{array}$ \\
\hline $\begin{array}{l}\text { Overall, how would you rate your institution in } \\
\text { readiness for EBP? }\end{array}$ & & & & $X$ & \\
\hline $\begin{array}{l}\text { Compared to } 6 \text { months ago, how much } \\
\text { movement in your organization has there } \\
\text { been toward an EBP culture? }\end{array}$ & None & & & & $\begin{array}{l}\text { A Great } \\
\text { Deal }\end{array}$ \\
\hline
\end{tabular}

(Copyright: Melnyk \& Fineout-Overholt, 2011, p 559; permission requested 11.2.11) 


\section{Appendix D}

NOUS FOUNDATION, Inc.

Federal ID\# 27-1871373

\section{Invoice}

Date: 10/24/2011

Invoice \# 086

To

ISNP

\begin{tabular}{|l|l|l|l|}
\hline Salesperson & Job & Payment Terms & Due Date \\
\hline & & Due on & January 1, \\
& & receipt & 2012 \\
\hline
\end{tabular}

\begin{tabular}{|l|l|l|l|}
\hline Qty & Description & Unit Price & Line Total \\
\hline $\begin{array}{l}\text { Licensing } \\
\text { agreement }\end{array}$ & $\begin{array}{l}\text { Access to ACP Video Library for 3 months } \\
\text { starting January 1, 2012 }\end{array}$ & $\$ 1,000$ & $\$ 1,000$ \\
\hline
\end{tabular}

Subtotal

$\$ 1,000$

Sales Tax

Total

$\$ 1,000$

Make all checks payable to Nous Foundation, Inc.

Thank you for your business!

Nous Foundation, Inc. 195 Carlton Road, Waban, MA 02468 Phone 866-440-5969 info@acpdecisions.org 
NOUS FOUNDATION, Inc.

Federal ID\# 27-1871373

Invoice

\section{Appendix E}

Date: 10/24/2011

Invoice \# 087

ISNP

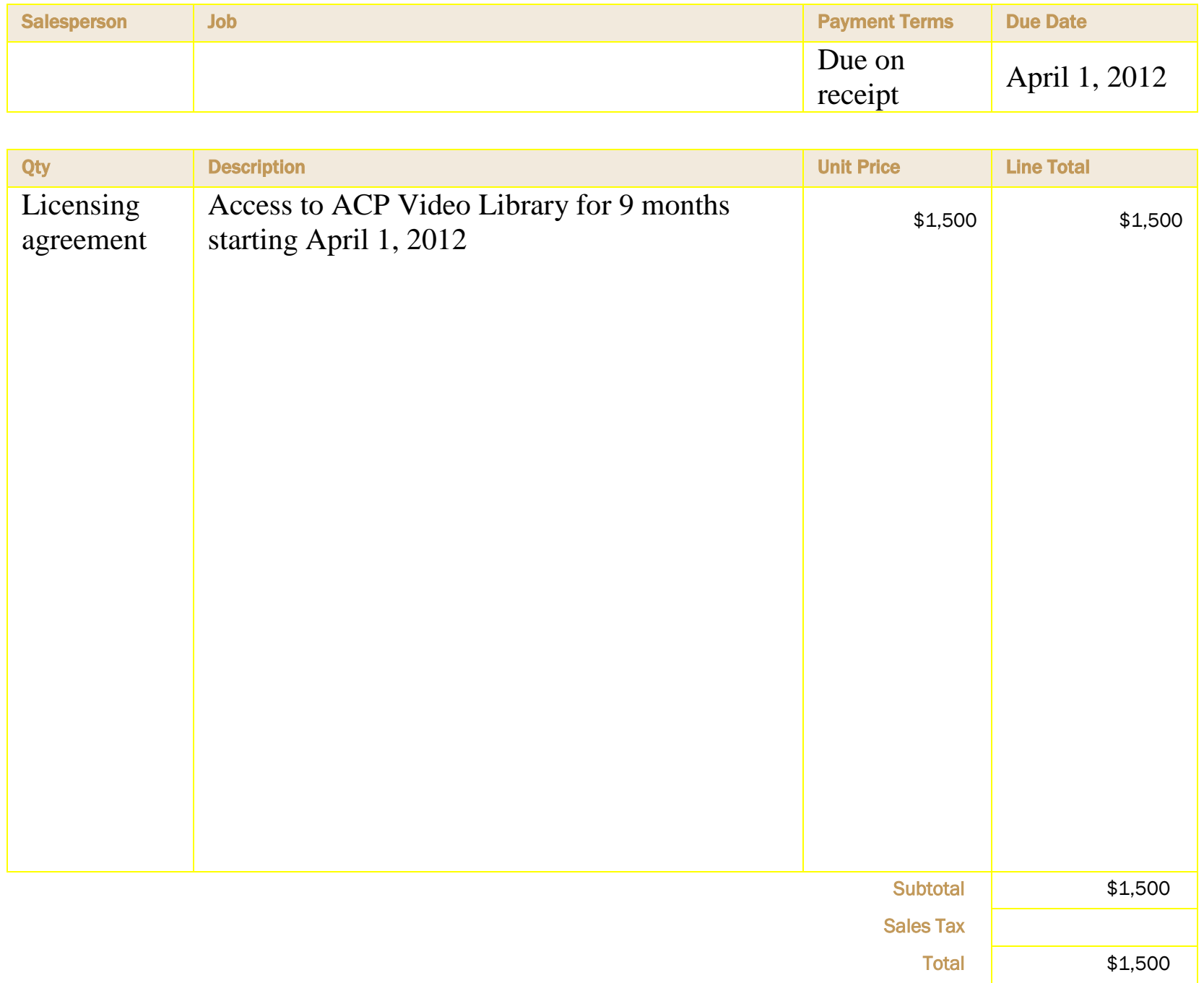

Make all checks payable to Nous Foundation, Inc.

Thank you for your business! 


\section{CPR Decisions in Nursing Home Residents M. Bennett DNP Candidate}

$-64-$

\section{Evaluation Table}

\section{Appendix F}

\begin{tabular}{|c|c|c|c|c|c|c|c|c|c|}
\hline $\begin{array}{l}\text { First } \\
\text { Author } \\
\text { (year) }\end{array}$ & $\begin{array}{l}\text { Conceptual } \\
\text { Framework }\end{array}$ & Design/Method & Sample/Setting & $\begin{array}{l}\text { Major Variables } \\
\text { Studied (and } \\
\text { Their } \\
\text { Definitions) }\end{array}$ & Measurement & $\begin{array}{l}\text { Data } \\
\text { Analysis }\end{array}$ & Findings & $\begin{array}{l}\text { Appraisal: } \\
\text { Worth to } \\
\text { Practice }\end{array}$ & \\
\hline $\begin{array}{l}\text { Ramsaroop, } \\
\text { SD, Reid, } \\
\text { MC, \& } \\
\text { Adelman, } \\
\text { RD } \\
(2007)\end{array}$ & N/A & $\begin{array}{l}\text { Level } 1 \\
\text { Meta analysis-18 } \\
\text { studies: } \\
12 \text { RCTs } \\
2 \text { Quasi } \\
2 \text { Prospective } \\
1 \text { Observational } \\
1 \text { retro cohort }\end{array}$ & $\begin{array}{l}\text { Selected } 18 \text { studies } \\
\text { Stated inclusion / } \\
\text { exclusion criteria }\end{array}$ & $\begin{array}{l}\text { Interventions to } \\
\text { increase Adv Dir } \\
\text { completion }\end{array}$ & $\begin{array}{l}18 \text { studies } \\
\text { looking at } \\
\text { interventions to } \\
\text { increase Adv Dir } \\
\text { completion }\end{array}$ & $\begin{array}{l}\text { Effect size } \\
\text { completed } \\
\text { on } 15 / 18 \\
\text { studies }\end{array}$ & $\begin{array}{l}\text { Studies } \\
\text { ranged from } \\
\text { completion } \\
\text { rates of } 44 \% \\
\text { to } \\
-2 \% \text { (favor } \\
\text { control) } \\
\text { Effect size } \\
\text { calc for } 15 \text { of } \\
18: \text { pooled } \\
\text { effect .50 } \\
(95 \% \text { CI }= \\
.17-.83 \text { ) } \\
\text { moderate } \\
\text { overall effect } \\
\text { favoring } \\
\text { intervention }\end{array}$ & $\begin{array}{l}\text { Very Strong: } \\
\text { Most success in } \\
\text { getting Adv Dir } \\
\text { completed is w/ } \\
\text { direct } \\
\text { interaction w/ } \\
\text { HCP } \\
\text { Passive } \\
\text { education- } \\
\text { written } \\
\text { materials w/o } \\
\text { counseling } \\
\text { ineffective }\end{array}$ & $\begin{array}{l}\text { Selected from hand } \\
\text { search of reference } \\
\text { lists of previously } \\
\text { selected studies }\end{array}$ \\
\hline $\begin{array}{l}\text { Volandes, } \\
\text { AE, } \\
\text { Paasche- } \\
\text { Oslow, } \\
\text { MK, } \\
\text { Barry, } \\
\text { MJ, } \\
\text { Gillick, } \\
\text { MR, } \\
\text { Minaker, } \\
\text { KL, } \\
\text { Chang, Y, } \\
\text { Cook, EF, } \\
\text { Abbo, } \\
\text { ED, El- } \\
\text { Jawahri, } \\
\text { A, }\end{array}$ & N/A & $\begin{array}{l}\text { Level II } \\
\text { RCT }\end{array}$ & $\begin{array}{l}\text { Convenience } \\
\text { sample > } 65 \text { yr; } \\
\text { Living in Boston } \\
\text { Community } \\
\text { dwelling } \\
4 \text { Primary care } \\
\text { clinics - } 2 \text { geri / } 2 \\
\text { adult } \\
\text { Mean age } 75 \text { yr } \\
58 \% \text { female } \\
\text { N=106 verbal grp } \\
\text { N=94 video grp }\end{array}$ & $\begin{array}{l}\text { IV=verbal narrative } \\
+ \text { video } \\
\text { DV=Selection of } \\
\text { comfort care, limited } \\
\text { life sustaining care, } \\
\text { or life prolonging } \\
\text { care } \\
\text { DV=change in } \\
\text { selection of care } \\
\text { level after } \\
\text { intervention and after } \\
6 \text { wk post } \\
\text { intervention } \\
\text { IV=Health Literacy }\end{array}$ & $\begin{array}{l}\text { Preferred goals of } \\
\text { care: } \\
\text { Life } \\
\text { Prolonging=vent } \\
+ \text { CPR } \\
\text { Limited } \\
\text { care=hosp / ATB } \\
\text { but no CPR } \\
\text { Comfort care= } \\
\text { symptom relief } \\
\text { interventions } \\
\text { Evaluated } \\
\text { selection of goals } \\
\text { of care after }\end{array}$ & $\begin{array}{l}\text { Odds ratio } \\
3.9 \text { for } \\
\text { video } \\
\text { group w/ } \\
95 \% \text { CI } \\
1.8-8.6 \\
\\
\mathrm{df}=3 \\
\mathrm{p}=.003\end{array}$ & $\begin{array}{l}\text { Verbal } \\
\text { narrative } \\
\text { only } \\
64 \% \text { comfort } \\
\text { care } \\
19 \% \text { Limited } \\
14 \% \text { Life } \\
\text { prolonging } \\
3 \% \text { uncertain } \\
\\
\text { Video grp } \\
86 \% \text { comfort } \\
9 \% \text { Limited } \\
4 \% \text { life } \\
\text { prolonging } \\
1 \% \text { uncertain } \\
6 \text { wk }\end{array}$ & $\begin{array}{l}\text { Strong worth to } \\
\text { practice: } \\
\text { Video re: adv } \\
\text { dementia } \\
\text { Participants } \\
\text { more likely to } \\
\text { select comfort } \\
\text { care over only } \\
\text { verbal } \\
\text { description } \\
\text { Video grp= } \\
\text { decision more } \\
\text { stable after } 6 \text { wk }\end{array}$ & $\begin{array}{l}\text { Tools: } 2 \text { min video } \\
\text { Www.ACPdecisio } \\
\underline{\text { ns.com }} \\
\text { Narrative appendix: } \\
\text { BMJ.com } \\
\text { Note to self: } \\
\text { Rural LA study used } \\
6 \text { min video; this was } \\
2 \text { min video } \\
\text { Difference?? }\end{array}$ \\
\hline
\end{tabular}




\section{CPR Decisions in Nursing Home Residents}

M. Bennett DNP Candidate

\begin{tabular}{|c|c|c|c|c|c|c|c|c|c|}
\hline $\begin{array}{l}\text { Mitchell, } \\
\text { SL } \\
\text { (2009) }\end{array}$ & & & & $\begin{array}{l}\text { tool: REALM } \\
\text { DV=correlation to } \\
\text { level of care selected }\end{array}$ & $\begin{array}{l}\text { intervention and } \\
\text { again } 6 \text { wk post } \\
\text { Health Literacy } \\
\text { assessed prior to } \\
\text { intervention as } \\
\text { part of } \\
\text { demographics }\end{array}$ & & $\begin{array}{l}\text { reinterview: } \\
\text { Verbal grp } \\
29 \% \text { change } \\
\text { in preference } \\
\text { Video grp } \\
6 \% \text { change in } \\
\text { preference } \\
\text { p<.001 }\end{array}$ & & \\
\hline $\begin{array}{l}\text { First } \\
\text { Author } \\
\text { (year) }\end{array}$ & $\begin{array}{l}\text { Conceptual } \\
\text { Framework }\end{array}$ & Design/Method & Sample/Setting & $\begin{array}{l}\text { Major Variables } \\
\text { Studied (and Their } \\
\text { Definitions) }\end{array}$ & Measurement & $\begin{array}{l}\text { Data } \\
\text { Analysis }\end{array}$ & Findings & $\begin{array}{l}\text { Appraisal: } \\
\text { Worth to } \\
\text { Practice }\end{array}$ & \\
\hline $\begin{array}{l}\text { Volandes, } \\
\text { AE, } \\
\text { Mitchell, } \\
\text { SL, } \\
\text { Gillick, } \\
\text { MR, } \\
\text { Chang, Y, } \\
\text { Paasche- } \\
\text { Oslow, } \\
\text { MK } \\
(2009)\end{array}$ & N/A & $\begin{array}{l}\text { Level II } \\
\text { RCT using } \\
\text { computer } \\
\text { randomization }\end{array}$ & $\begin{array}{l}\text { Convenience } \\
\text { sample } \\
\mathrm{N}=14 \\
2 \text { geri clinics in } \\
\text { Boston } \\
\text { Note_-subgrp of } \\
\text { BMJ study above } \\
\text { During same time } \\
\text { period } \\
\text { Narrative }=6 \\
\text { Video=8 }\end{array}$ & $\begin{array}{l}\text { IV_-video of adv } \\
\text { dementia } \\
\text { DV=Selection of } \\
\text { comfort care, limited } \\
\text { life sustaining care, } \\
\text { or life prolonging } \\
\text { care } \\
\text { DV=concordance of } \\
\text { pt decision w/ } \\
\text { surrogate decision } \\
\text { maker } \\
\text { DV=acceptability of } \\
\text { video } \\
\text { DV=recommendation } \\
\text { of video } \\
\text { DV=knowledge of } \\
\text { adv dementia }\end{array}$ & $\begin{array}{l}\text { Preferred goals of } \\
\text { care: } \\
\text { Life } \\
\text { Prolonging=vent } \\
+ \text { CPR } \\
\text { Limited } \\
\text { care=hosp / ATB } \\
\text { but no CPR } \\
\text { Comfort care= } \\
\text { symptom relief } \\
\text { interventions } \\
\text { Concordance: } \\
\text { Agreement } \\
\text { between pt \& } \\
\text { surrogate on } \\
\text { decision of goal } \\
\text { of care }\end{array}$ & $\begin{array}{l}\text { Tabulation } \\
\text { statistics }\end{array}$ & $\begin{array}{l}\text { Verbal grp: } \\
50 \% \text { comfort } \\
\text { care } \\
17 \% \text { limited } \\
33 \% \text { life } \\
\text { prolonging } \\
\text { Concordance: } \\
33 \% \text { 2/6 } \\
\text { agreement } \\
\text { between } \\
\text { surrogate \& } \\
\text { pt } \\
\text { Video grp: } \\
100 \% \\
\text { comfort care } \\
100 \% \\
\text { Concordance } \\
\text { w/ Video and } \\
\text { surrogates w/ } \\
\text { patient } \\
\text { Acceptability } \\
\text { of video } 94 \% \\
\text { Recommend } \\
\text { video to } \\
\text { others: } 94 \% \\
\text { Knowledge } \\
\text { inc in both } \\
\text { grps }\end{array}$ & $\begin{array}{l}\text { Strong worth to } \\
\text { practice: } \\
\text { Video re: adv } \\
\text { dementia } \\
\text { Participants } \\
\text { more likely to } \\
\text { select comfort } \\
\text { care over only } \\
\text { verbal } \\
\text { description }\end{array}$ & $\begin{array}{l}\text { Limitations: } \\
\text { Researcher not blind } \\
\text { Small sample } \\
\text { Video bias possible } \\
\text { Lack minorities }\end{array}$ \\
\hline
\end{tabular}




\section{CPR Decisions in Nursing Home Residents}

$-67-$

\section{Bennett DNP Candidate}

\begin{tabular}{|c|c|c|c|c|c|c|c|c|c|}
\hline $\begin{array}{l}\text { First } \\
\text { Author } \\
\text { (year) }\end{array}$ & $\begin{array}{l}\text { Conceptual } \\
\text { Framework }\end{array}$ & Design/Method & Sample/Setting & $\begin{array}{l}\text { Major Variables } \\
\text { Studied (and } \\
\text { Their } \\
\text { Definitions) }\end{array}$ & Measurement & $\begin{array}{l}\text { Data } \\
\text { Analysis }\end{array}$ & Findings & $\begin{array}{l}\text { Appraisal: } \\
\text { Worth to } \\
\text { Practice }\end{array}$ & \\
\hline $\begin{array}{l}\text { Volandes, } \\
\text { AE, } \\
\text { Ferguson, } \\
\text { Davis, } \\
\text { Hull, } \\
\text { Green, } \\
\text { Chang, Y, } \\
\text { Deep, } \\
\text { Paasche- } \\
\text { Oslow } \\
\text { (2011) }\end{array}$ & N/A & $\begin{array}{l}\text { Level II } \\
\text { RCT }\end{array}$ & $\begin{array}{l}\text { Primary care clinic } \\
\text { rural Louisiana } \\
\geq 65 \mathrm{yr} \\
\mathrm{N}=76\end{array}$ & $\begin{array}{l}\text { IV_-video of adv } \\
\text { dementia } \\
\text { IV_-Health Literacy } \\
\text { w/ REALM } \\
\text { DV=Selection of } \\
\text { comfort care, limited } \\
\text { life sustaining care, } \\
\text { or life prolonging } \\
\text { care } \\
\text { DV=concordance of } \\
\text { pt decision w/ } \\
\text { surrogate decision } \\
\text { maker } \\
\text { DV=acceptability of } \\
\text { video } \\
\text { DV=recommendation } \\
\text { of video } \\
\text { DV=knowledge of } \\
\text { adv dementia }\end{array}$ & $\begin{array}{l}\text { Preferred goals of } \\
\text { care: } \\
\text { Life Prolonging=vent } \\
+ \text { CPR } \\
\text { Limited care=hosp / } \\
\text { ATB but no CPR } \\
\text { Comfort care }= \\
\text { symptom relief } \\
\text { interventions } \\
\text { Health Literacy } \\
\text { assessed prior to } \\
\text { intervention as part of } \\
\text { demographics } \\
4 \text { pt Likert scale to } \\
\text { assess perceived value } \\
\text { of video: } \\
1=\text { inc understanding } \\
2=\text { recommend to } \\
\text { others } \\
3 \text { Levels of Literacy } \\
\text { based on score: } \\
\text { Low literacy }=0-45 \\
=6^{\text {th }} \text { grade and below } \\
\text { Marginal }=45-60= \\
7^{\text {th }}-8^{\text {th }} \text { grade } \\
\text { Adequate }=61-66=9^{\text {th }} \\
\text { grade } \& \text { above }\end{array}$ & 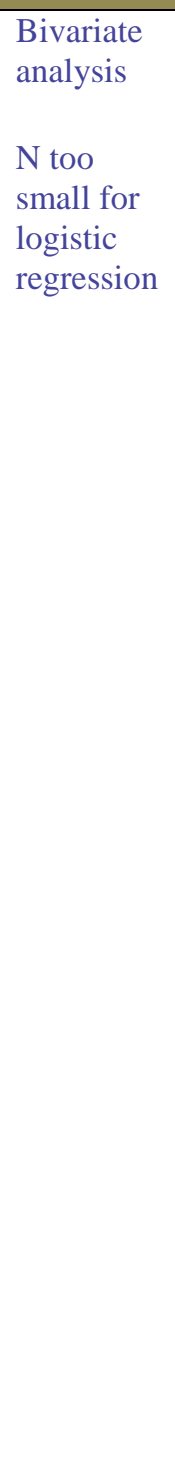 & $\begin{array}{l}\text { Verbal narrative } \\
\text { only (control } \\
\text { group) } \\
72 \% \text { comfort } \\
\text { care } \\
\text { 12\% Limited } \\
\text { 16\% Life } \\
\text { prolonging } \\
\text { Video grp } \\
91 \% \text { comfort } \\
\text { 9\% Limited } \\
\text { 0\% life } \\
\text { prolonging } \\
\text { df=2 } \\
\text { p=.047 } \\
\text { Greater health } \\
\text { literacy led to } \\
\text { increase selection } \\
\text { of comfort } \\
\text { OR 2.1 } \\
\text { 95\% CI } \\
\text { CI 2.4 -62.6 } \\
\text { Video grp more } \\
\text { likely to select } \\
\text { comfort care } \\
\text { OR 3.9 } \\
\text { CI 95\% } \\
\text { CI 1.0-15.1 } \\
\text { Perceived value } \\
\text { of video: } \\
31 / 33 \text { very or } \\
\text { somewhat } \\
\text { helpful } \\
32 / 33 \\
\text { recommend to }\end{array}$ & $\begin{array}{l}\text { Strong worth } \\
\text { to practice }\end{array}$ & $\begin{array}{l}\text { Note: } \\
\text { Researcher } \\
\text { not blinded } \\
\text { 6min video in } \\
\text { this study vs } 2 \\
\text { min in } 2009 \\
\text { study } \\
\text { Difference?? } \\
\text { Health } \\
\text { Literacy } \\
\text { confounds } \\
\text { role of race } \\
\text { Narrative is } \\
\text { included in } \\
\text { appendix }\end{array}$ \\
\hline
\end{tabular}


CPR Decisions in Nursing Home Residents

$-68-$

M. Bennett DNP Candidate

\begin{tabular}{|c|c|c|c|c|c|c|c|c|c|}
\hline $\begin{array}{l}\text { First } \\
\text { Author } \\
\text { (year) }\end{array}$ & $\begin{array}{l}\text { Conceptual } \\
\text { Framework }\end{array}$ & Design/Method & Sample/Setting & $\begin{array}{l}\text { Major Variables } \\
\text { Studied (and } \\
\text { Their } \\
\text { Definitions) }\end{array}$ & Measurement & $\begin{array}{l}\text { Data } \\
\text { Analysis }\end{array}$ & Findings & $\begin{array}{l}\text { Appraisal: } \\
\text { Worth to } \\
\text { Practice }\end{array}$ & \\
\hline $\begin{array}{l}\text { Johnson, } \\
\text { HM, } \\
\text { Nelson, A } \\
\text { (2008) }\end{array}$ & $\begin{array}{l}\text { Interpretative } \\
\text { Phenomenological } \\
\text { Analysis (IPA) }\end{array}$ & $\begin{array}{l}\text { Level VI } \\
\text { Qualitative } \\
\text { Semi-structured } \\
\text { interviews }\end{array}$ & $\begin{array}{l}\text { UK } \\
\text { Hospice inpatient } \\
\& \text { day } \\
\mathrm{N}=6 \\
13 \text { approached } \\
2 \text { declined d/t topic } \\
4 \text { too ill } \\
1 \text { aphasic } \\
6 \text { included } \\
5 \text { inpatient } \\
1 \text { day unit }\end{array}$ & $\begin{array}{l}\text { IV_-Informational } \\
\text { Leaflet on CPR } \\
\text { DV_patient views } \\
\text { on acceptability of } \\
\text { leaflet } \\
\text { DV_patient } \\
\text { understanding of } \\
\text { CPR from leaflet }\end{array}$ & $\begin{array}{l}\text { Qualitative- } \\
\text { emergent themes } \\
\text { based on } \\
\text { interviews }\end{array}$ & $\begin{array}{l}\text { Grouping of } \\
\text { emergent } \\
\text { themes }\end{array}$ & $\begin{array}{l}\text { Leaflet was } \\
\text { acceptable to } \\
\text { participants } \\
\text { Leaflet was } \\
\text { not a reliable } \\
\text { method to } \\
\text { communicate } \\
\text { CPR and } \\
\text { needs } \\
\text { discussion \& } \\
\text { opportunity } \\
\text { to clarify \& } \\
\text { ask questions }\end{array}$ & $\begin{array}{l}\begin{array}{l}\text { Weak- } \\
\text { small } \\
\text { convenience } \\
\text { sample }\end{array} \\
\text { Population } \\
\text { not easily } \\
\text { generalizable } \\
\text { due to UK } \\
\text { but may be } \\
\text { similar to nsg } \\
\text { home rdts }\end{array}$ & $\begin{array}{l}\text { In UK-CPR } \\
\text { futile, physician } \\
\text { can defer } \\
\text { discussion and } \\
\text { inform patient } \\
\text { CPR will not be } \\
\text { offered; } \\
\text { If pt refuses to } \\
\text { participate in } \\
\text { discussion, } \\
\text { physician can } \\
\text { order DNAR }\end{array}$ \\
\hline $\begin{array}{l}\text { Frank, C, } \\
\text { Pichora, D, } \\
\text { Suurdt, J, } \\
\text { Heyland, D. } \\
\\
\text { (2009) }\end{array}$ & N/A & $\begin{array}{l}\text { Level IV } \\
\text { Cohort study }\end{array}$ & $\begin{array}{l}\text { Canadian hospital } \\
\mathrm{N}=36 \\
25 \text { patients }+11 \\
\text { family members } \\
\text { Inpatients }>55 \mathrm{yr} \\
\text { w/ serious illnesses }\end{array}$ & $\begin{array}{l}\text { IV Decision aid re: } \\
\text { CPR for hospitalized } \\
\text { patients } \\
\text { DV=acceptability of } \\
\text { decision aid } \\
\text { DV=burden w/ use } \\
\text { DV=recommendation } \\
\text { for use w/ others }\end{array}$ & $\begin{array}{l}\text { Acceptability of } \\
\text { decision aid } \\
\text { Burden w/ use } \\
\text { Recommendation } \\
\text { to use w/ others }\end{array}$ & $\begin{array}{l}\text { Tabulation } \\
\text { statistics }\end{array}$ & $\begin{array}{l}92 \% \text { patients } \\
\& 64 \% \\
\text { families } \\
\text { stated } \\
\text { decision aid } \\
\text { was very or } \\
\text { extremely } \\
\text { helpful } \\
>70 \% \\
\text { patients \& } \\
\text { families } \\
\text { considered } \\
\text { aid } \\
\text { acceptable } \\
\text { Low burden } \\
\text { median } 2 / 10 \\
\text { on } 10 \text { pt } \\
\text { scale of } \\
1=n o n e ~ \& ~\end{array}$ & $\begin{array}{l}\text { Weak- } \\
\text { small } \\
\text { sample, } \\
\text { hospitalized } \\
\text { population }\end{array}$ & $\begin{array}{l}\text { Comment-- } \\
\text { should be done } \\
\text { by a nurse--they } \\
\text { are better } \\
\text { communicators } \\
\text { (than docs) }\end{array}$ \\
\hline
\end{tabular}




\section{CPR Decisions in Nursing Home Residents}

$-69-$

\section{Bennett DNP Candidate}

\begin{tabular}{|c|c|c|c|c|c|c|c|c|c|}
\hline & & & & & & & $\begin{array}{l}10=\text { extremely } \\
\text { upsetting } \\
100 \% \\
\text { recommended } \\
\text { use w/ others }\end{array}$ & & \\
\hline $\begin{array}{l}\text { First } \\
\text { Author } \\
\text { (year) }\end{array}$ & $\begin{array}{l}\text { Conceptual } \\
\text { Framework }\end{array}$ & Design/Method & Sample/Setting & $\begin{array}{l}\text { Major } \\
\text { Variables } \\
\text { Studied } \\
\text { (and Their } \\
\text { Definitions) }\end{array}$ & Measurement & $\begin{array}{l}\text { Data } \\
\text { Analysis }\end{array}$ & Findings & $\begin{array}{l}\text { Appraisal: } \\
\text { Worth to } \\
\text { Practice }\end{array}$ & \\
\hline $\begin{array}{l}\text { Van Mil, } \\
\text { AHM, van } \\
\text { Klink, RCJ, } \\
\text { Juntjens, C, } \\
\text { Westerndorp, } \\
\text { RGJ, } \\
\text { Stiggelbout, } \\
\text { AM, } \\
\text { Meinders, } \\
\text { AE, Lagaay, } \\
\text { AM } \\
(2000)\end{array}$ & N/A & \begin{tabular}{|l} 
Level VI \\
Qualitative study \\
Study impact of \\
gender, \\
information, \\
quality of life \\
(QOL) \& \\
hospitalization on \\
CPR discussions \& \\
preferences \\
\\
Interviews- \\
CPR preferences \\
Current state of \\
health \\
3 hypothetical \\
scenarios
\end{tabular} & $\begin{array}{l}\text { Netherlands } \\
75 \text { community } \\
\text { dwelling elders in } \\
\text { Leiden w/ MMSE } \\
>24 \\
45 \text { consecutive } \\
\text { patients in } 2 \\
\text { hospitals in Leiden } \\
\geq 75 \mathrm{yr} \\
\mathrm{N}=120\end{array}$ & $\begin{array}{l}\text { CPR survival } \\
\text { knowledge } \\
\text { QOL w/ CPR }\end{array}$ & $\begin{array}{l}\text { Expected survival w/ } \\
\text { CPR for } 3 \text { situations: } \\
\text { a. acute illness } \\
\text { b. chronic illness } \\
\text { c. terminal CA } \\
\text { Preferences for CPR in } \\
\text { above situations } \\
\text { Then interviewer shared } \\
\text { survival info: 10-17\% } \\
\text { survival w/ acute illness; } \\
<5 \% \text { survival w/ chronic } \\
\text { illness and 0-5\% } \\
\text { survival w/ terminal CA } \\
\text { Rated QOL w/ } \\
\text { Dartmouth COOP / } \\
\text { WONCA functional } \\
\text { health assessment } \\
\text { Desire for info } \\
\text { Desire to participate in } \\
\text { CPR discussion } \\
\text { Preferred time to discuss }\end{array}$ & $\begin{array}{l}\text { QOL } \\
\text { multivariate } \\
\text { regression }\end{array}$ & $\begin{array}{l}\text { Survival w/ CPR } \\
\text { over-estimated } \\
\text { Males CPR } \\
\text { preferences assoc w/ } \\
\text { pain } \\
\text { Female CPR } \\
\text { preference assoc w/ } \\
\text { impaired physical } \\
\text { function \& daily } \\
\text { social activities } \\
\text { 6\% had prior CPR } \\
\text { discussions w/ MD } \\
\text { 70\% preferred } \\
\text { routine discussions } \\
\text { 61\% wanted to make } \\
\text { own decision } \\
\text { 65\% not want CPR } \\
\text { after discussion (not } \\
\text { measure prior) } \\
\text { Gender difference in } \\
\text { CPR not r/t QOL } \\
\text { indicators }\end{array}$ & Moderate & \begin{tabular}{|l} 
Note: \\
Popular TV \\
contributes \\
to belief \\
CPR is more \\
successful
\end{tabular} \\
\hline
\end{tabular}




\section{CPR Decisions in Nursing Home Residents \\ M. Bennett DNP Candidate}

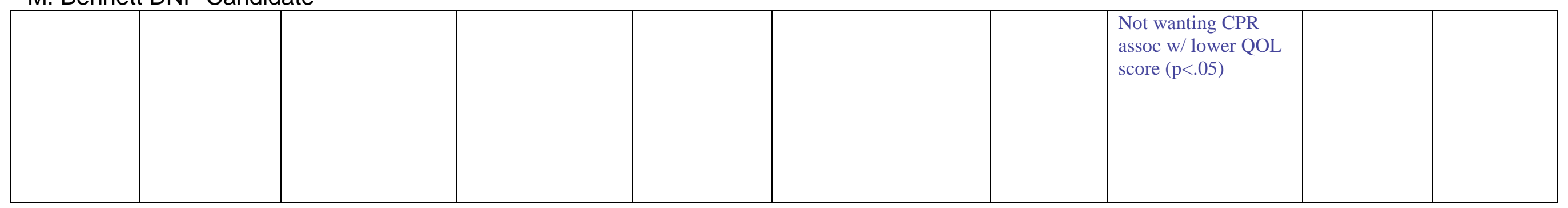

\begin{tabular}{|c|c|c|c|c|c|c|c|c|c|}
\hline $\begin{array}{l}\text { First } \\
\text { Author } \\
\text { (year) }\end{array}$ & $\begin{array}{l}\text { Conceptual } \\
\text { Framework }\end{array}$ & Design/Method & Sample/Setting & $\begin{array}{l}\text { Major } \\
\text { Variables } \\
\text { Studied } \\
\text { (and Their } \\
\text { Definitions) }\end{array}$ & Measurement & $\begin{array}{l}\text { Data } \\
\text { Analysis }\end{array}$ & Findings & $\begin{array}{l}\text { Appraisal: } \\
\text { Worth to } \\
\text { Practice }\end{array}$ & \\
\hline $\begin{array}{l}\text { Molloy, } \\
\text { DW, } \\
\text { Guyatt, } \\
\text { GH } \\
\text { Russo, R, } \\
\text { Goeree, } \\
\text { R, } \\
\text { O’Brien, } \\
\text { BJ, } \\
\text { Bedard, } \\
\text { M } \\
\text { Et al. } \\
\text { (2000) }\end{array}$ & $\begin{array}{l}\text { Let Me Decide } \\
\text { Adv Dir } \\
\text { Program } \\
\text { (LMD) }\end{array}$ & $\begin{array}{l}\text { Level II } \\
\text { RCT }\end{array}$ & \begin{tabular}{|l|} 
Ontario \\
6 nsg homes \\
Matched pairs on \\
key characteristics \\
1 per pair to \\
intervention grp \\
Controls continued \\
w/ prior policies \\
\\
$\mathrm{N}=1292$ total \\
$\mathrm{N}=527$ \\
intervention grp \\
\\
Decisional=MMSE \\
$\geq 16$ \\
Family contacted if \\
MMSE $<16$
\end{tabular} & $\begin{array}{l}\text { IV=Let Me } \\
\text { Decide Adv } \\
\text { Dir program } \\
\text { DV=family /pt } \\
\text { satisfaction } \mathrm{w} / \\
\text { care, services } \\
\& \text { costs }\end{array}$ & $\begin{array}{l}7 \text { pt Likert satisfaction } \\
\text { scale at } 4 \text { points: } \\
\text { Start, } 6,12 \text { and } 18 \text { mo } \\
\text { Hospitalizations } \\
\text { Cost of hospitalization } \\
\text { Completion of LMD }\end{array}$ & $\begin{array}{l}\text { CI } \\
\% \\
\text { Means } \\
\text { significance }\end{array}$ & $\begin{array}{l}49 \% \text { decisional } \\
\text { rdts completed } \\
\text { LMD } \\
78 \% \text { families of } \\
\text { rdts w/o } \\
\text { decisional } \\
\text { capacity } \\
\text { completed LMD } \\
\text { Satisfaction not } \\
\text { statistically } \\
\text { different between } \\
\text { intervention grp } \\
\text { and control grp } \\
-.16 \text { CI } 95 \% \text { Rdt } \\
.07 \text { CI } 95 \% \\
\text { family } \\
\text { Intervention grp } \\
\text { fewer } \\
\text { hospitalizations } \\
\text { than cntrl-mean } \\
0.27 \text { vs } 0.48 \\
\text { p=.001 } \\
\text { Decreased }\end{array}$ & $\begin{array}{l}\text { Strong worth } \\
\text { to practice }\end{array}$ & $\begin{array}{l}\text { LMD program } \\
\text { includes } \\
\text { instructional } \\
\text { and proxy } \\
\text { components; } \\
\text { range of } \\
\text { health care } \\
\text { choices: life } \\
\text { threatening } \\
\text { illness } \\
\text { (intensive to } \\
\text { palliative), } \\
\text { cardiac arrest } \\
\text { (CPR / } \\
\text { DNAR), } \\
\text { feeding } \\
\text { (intubation to } \\
\text { basic:-; in a } \\
\text { reversible } \\
\text { condition w/ } \\
\text { acceptable } \\
\text { quality of life } \\
\text { vs irreversible } \\
\text { condition w/ } \\
\text { unacceptable } \\
\text { quality of life }\end{array}$ \\
\hline
\end{tabular}




\section{CPR Decisions in Nursing Home Residents \\ M. Bennett DNP Candidate}

$-71-$

\begin{tabular}{|c|c|c|c|c|c|c|c|c|c|}
\hline & & & & & & & \begin{tabular}{|l|} 
utilization of \\
services w/o \\
change in \\
mortality or \\
satisfaction \\
Resource cost \\
$\$ 3490$ vs $\$ 5239$ \\
(Canadian) p=.01 \\
\\
Deaths: \\
$24 \%$ Intervention \\
$28 \%$ cntrl grp \\
$p=.20$
\end{tabular} & & \\
\hline $\begin{array}{l}\text { First } \\
\text { Author } \\
\text { (year) }\end{array}$ & $\begin{array}{l}\text { Conceptual } \\
\text { Framework }\end{array}$ & Design/Method & Sample/Setting & $\begin{array}{l}\text { Major } \\
\text { Variables } \\
\text { Studied } \\
\text { (and Their } \\
\text { Definitions) } \\
\end{array}$ & Measurement & $\begin{array}{l}\text { Data } \\
\text { Analysis }\end{array}$ & Findings & $\begin{array}{l}\text { Appraisal: } \\
\text { Worth to } \\
\text { Practice }\end{array}$ & \\
\hline $\begin{array}{l}\text { Laakkonen, } \\
\text { ML, } \\
\text { Pitkala, } \\
\text { KH, } \\
\text { Strandberg, } \\
\text { TE, } \\
\text { Berglind, } \\
\text { S, Tilvis, } \\
\text { RS } \\
\text { (2005) }\end{array}$ & N/A & $\begin{array}{l}\text { Level VI } \\
\text { Descriptive study }\end{array}$ & $\begin{array}{l}\text { Finland } \\
\mathrm{N}=220 \\
\text { Elderly, home } \\
\text { dwelling CV } \\
\text { patients } \geq 75 \mathrm{yr} \\
\text { Part of DEBATE } \\
\text { study } \\
\text { CV=atherosclerotic } \\
\text { dx, prior MI, CAD, } \\
\text { prior CVA, TIA, } \\
\text { PAD }\end{array}$ & $\begin{array}{l}\text { CPR } \\
\text { preferences } \\
\text { QOL } \\
\text { Zung } \\
\begin{array}{l}\text { Depression } \\
\text { score }\end{array}\end{array}$ & $\begin{array}{l}\text { Rationale for CPR } \\
\text { preferences } \\
\text { Decision making } \\
\text { process } \\
\text { Physical function } \\
\text { Cognition } \\
\text { Mood } \\
\text { QOL } \\
\text { Questionnaire for } \\
\text { demographics } \\
\text { Zung Depression scale } \\
\text { MMSE at annual clinic } \\
\text { visit }\end{array}$ & $\begin{array}{l}\text { NCSS } \\
\text { stats } \\
\text { program }\end{array}$ & $\begin{array}{l}52 \% \text { estimated CPR } \\
\text { outcome better than } \\
\text { those refusing CPR } \\
9 \% \text { had discussed } \\
38 \% \text { want to discuss } \\
\text { 80\% felt patient } \\
\text { should be involved- } \\
\text { alone, w/ doc or w/ } \\
\text { doc \& family } \\
\text { No difference assoc } \\
\text { w/ religion in CPR vs } \\
\text { nonCPR grp } \\
\text { 92\% of non CPR grp } \\
\text { had "gained old age \& } \\
\text { had a full life" } \\
114 / 220(52 \%) \\
\text { wanted CPR "life is }\end{array}$ & Moderate & $\begin{array}{l}\text { ACP as a } \\
\text { developmental } \\
\text { task }\end{array}$ \\
\hline
\end{tabular}


CPR Decisions in Nursing Home Residents M. Bennett DNP Candidate

\begin{tabular}{l} 
M. Bennett DNP Candidate \\
\begin{tabular}{|l|l|l|l|l|l|l|}
\hline & & & & & precious; feel needed \\
by family or friends; \\
life has value of its \\
own" \\
$48 \%$ non CPR \\
$16 \%$ Zung score $>44$ \\
which is depression \\
Depression assoc w/ \\
refusing CPR/ \\
preferring less \\
treatment \\
$40 \%$ presumed CPR \\
outcome good or \\
moderate
\end{tabular} \\
\hline
\end{tabular}

$-72-$ 


\section{CPR Decisions in Nursing Home Residents}

\section{Bennett DNP Candidate}

\begin{tabular}{|c|c|c|c|c|c|c|c|c|}
\hline $\begin{array}{l}\text { First } \\
\text { Author } \\
\text { (year) }\end{array}$ & $\begin{array}{l}\text { Conceptual } \\
\text { Framework }\end{array}$ & Design/Method & Sample/Setting & $\begin{array}{l}\text { Major } \\
\text { Variables } \\
\text { Studied } \\
\text { (and Their } \\
\text { Definitions) }\end{array}$ & Measurement & $\begin{array}{l}\text { Data } \\
\text { Analysis }\end{array}$ & Findings & $\begin{array}{l}\text { Appraisal: } \\
\text { Worth to } \\
\text { Practice }\end{array}$ \\
\hline $\begin{array}{l}\text { Levy, C, } \\
\text { Morris, } \\
\text { M, \& } \\
\text { Kramer, } \\
\text { A } \\
\text { (2008) }\end{array}$ & N/A & $\begin{array}{l}\text { Level IV } \\
\text { Cohort, } \\
\text { retrospective chart } \\
\text { review } \\
\text { Compare } 1 \text { yr prior } \\
\text { and } 1 \text { yr after } \\
\text { implementation of } \\
\text { Making Advance } \\
\text { Planning a Priority } \\
\text { (MAPP) } \\
\\
\text { Rdts identified at } \\
\text { risk for death } \\
\text { (score } \geq 7) \\
\text { Fax sent to MD re: } \\
\text { risk status } \\
\text { Chart flagged re: } \\
\text { risk status } \\
\text { MD had to respond } \\
\text { to } 4 \text { options: } 1 . \\
\text { EOL needs already } \\
\text { addressed \& state } \\
\text { date of note in } \\
\text { chart. 2. state } \\
\text { would address on } \\
\text { next visit and give } \\
\text { date of next visit. } \\
3 . \text { refer rdt for } \\
\text { palliative care } \\
\text { consult } 4 \text {. refer } \\
\text { for hospice consult }\end{array}$ & $\begin{array}{l}\text { Colorado } \\
\text { Urban } 160 \text { bed nsg } \\
\text { home, for profit, } \\
\text { chain } \\
\text { Census } 123 / 160 \\
\text { avg } \\
\text { N=72 with } 27 \text { pre } \\
\text { and } 45 \text { post }\end{array}$ & $\begin{array}{l}\text { IV= MAPP } \\
\text { Making } \\
\text { Advance } \\
\text { Planning a } \\
\text { Priority } \\
\text { (MAPP) } \\
\text { program } \\
\text { DV= site of } \\
\text { death } \\
\text { DV=presence } \\
\text { of Adv Dir } \\
\text { DV=presence } \\
\text { of CPR order } \\
\text { DV= presence } \\
\text { of hospice or } \\
\text { palliative care } \\
\text { w/ death } \\
\text { DV=length of } \\
\text { hospice before } \\
\text { death }\end{array}$ & $\begin{array}{l}\text { MAPP_identified rdts } \\
\text { at high risk of death } \\
\text { using MDS mortality } \\
\text { prediction based on: } \\
\text { Wt loss, male sex, } \\
\text { functional ability, } \\
\text { swallowing problem, } \\
\text { SOB, age } \geq 88, \text { BMI } \leq 22 \text {; } \\
\text { Dx CHF } \\
\text { Score } 0-2=7 \% \\
\text { probability of death in } \\
12 \text { months } \\
\text { Score } 3-6=19 \% \\
\text { probability of death in } \\
12 \text { months } \\
\text { Score } 7-10=50 \% \\
\text { probability of death in } \\
12 \text { months } \\
\text { Score } \geq 11=87 \% \text { chance } \\
\text { of death in } 12 \text { months } \\
\text { (Flacker Mortality tool) } \\
\text { CPS = cognitive } \\
\text { performance score } \\
\text { Barthel Index = } \\
\text { functional ability using } \\
\text { ADL scores }\end{array}$ & $\begin{array}{l}\text { SPSS } \\
\begin{array}{l}\text { Logistic } \\
\text { regression }\end{array} \\
\text { Student } t \\
\text { test } \\
\text { Wilcoxon }\end{array}$ & $\begin{array}{l}\text { Following MAPP: } \\
\text { Rdts less likely to die } \\
\text { in hospital—48.2\% } \\
\text { prior vs } 8.9 \% \text { post } \\
\text { MAPP, p=.0001 } \\
\text { 100\% rdts dying } \\
\text { after MAPP program } \\
\text { started, had Adv Dir } \\
\text { in place (p=.03) } \\
\text { Rdts more likely to } \\
\text { have palliative care } \\
\text { referrals- pre7.4\%; } \\
\text { post } 31.1 \%, \text { p=.02 } \\
\text { Mean number of } \\
\text { hosp days prior to } \\
\text { death did not } \\
\text { decrease- }-5.17 \text { pre } \\
\text { vs } 3.33 \text { post, p=.42 } \\
\text { No change in hospice } \\
\text { referrals pre and post } \\
\text { Mean LOS in } \\
\text { hospice did not } \\
\text { change-pre } 15.1 \pm \\
24.3 \text { days vs post } \\
24.3 \pm 32.7 \text { days; } \\
\text { p=.51 } \\
\text { Prior: } 12 \% \text { rdts no } \\
\text { Adv Dir at all; vs all } \\
\text { had Adv Dir post } \\
\text { Pre } 63 \% \text { DNR } \\
\text { orders; Post } 84.4 \% \\
\text { DNR orders (p=.003) }\end{array}$ & $\begin{array}{l}\text { Strong worth to } \\
\text { practice-may } \\
\text { have reflected } \\
\text { increased focus } \\
\text { by facility staff } \\
\text { on obtaining Adv } \\
\text { Dir and use } \\
\text { Researchers } \\
\text { excluded rdts } \\
\text { who died in } \\
\text { hospital if in } \\
\text { hospital greater } \\
\text { than } 2 \text { weeks } \\
\\
\text { Study sample had } \\
\text { more African } \\
\text { Americans than } \\
\text { general Colorado } \\
\text { population (pre } \\
18.5 \% \text {; post } \\
11.1 \% \text { and gnrl } \\
\text { pop 3.8\%) }\end{array}$ \\
\hline
\end{tabular}




\section{CPR Decisions in Nursing Home Residents \\ M. Bennett DNP Candidate}

\begin{tabular}{|c|c|c|c|c|c|c|c|c|}
\hline $\begin{array}{l}\text { First } \\
\text { Author } \\
\text { (year) }\end{array}$ & $\begin{array}{l}\text { Conceptual } \\
\text { Framework }\end{array}$ & Design/Method & Sample/Setting & $\begin{array}{l}\text { Major } \\
\text { Variables } \\
\text { Studied } \\
\text { (and Their } \\
\text { Definitions) }\end{array}$ & Measurement & $\begin{array}{l}\text { Data } \\
\text { Analysis }\end{array}$ & Findings & $\begin{array}{l}\text { Appraisal: } \\
\text { Worth to } \\
\text { Practice }\end{array}$ \\
\hline $\begin{array}{l}\text { McBee, L, } \\
\text { Burack, } \\
\text { OR, Carter, } \\
\text { JM, } \\
\text { Chichin, } \\
\text { ER } \\
(2000)\end{array}$ & N/A & $\begin{array}{l}\text { Level VI } \\
\text { QI Project } \\
\text { identified by team } \\
\text { in nsg home }\end{array}$ & $\begin{array}{l}\text { NYC using } 3 \text { units } \\
\text { of a nsg home } \\
\text { N=58 }\end{array}$ & $\begin{array}{l}\text { IV=contact w/ } \\
\text { family } \\
\text { DV=complete } \\
\text { Adv Dir }\end{array}$ & $\begin{array}{l}\text { Tracking form for \# of } \\
\text { time contacted / spoke } \\
\text { w/ family }\end{array}$ & $\begin{array}{l}\% \\
\text { Calculate } \\
\text { time } \\
\text { period }\end{array}$ & $\begin{array}{l}40 \% \text { families made } \\
\text { ACP decision } \\
\text { when contacted } \\
80 \% \text { made decision } \\
\text { within } 1 \text { month } \\
17 \% \text { never made } \\
\text { decision } \\
\text { Majority of } \\
\text { decisions made w/ } \\
4 \text { attempts to } \\
\text { contact family }\end{array}$ & $\begin{array}{l}\text { Weak but shows } \\
\text { persistence results } \\
\text { in increased } \\
\text { completion rates }\end{array}$ \\
\hline $\begin{array}{l}\text { Sudore, } \\
\text { RL, \& } \\
\text { Fried, TR } \\
\text { (2010) }\end{array}$ & N/A & $\begin{array}{l}\text { Level V } \\
\text { Synthesis of } \\
\text { literature review }\end{array}$ & N/A & N/A & N/A & N/A & $\begin{array}{l}\text { Identifies } 3 \text { steps to } \\
\text { prepare patient \& } \\
\text { surrogate: } \\
\text { 1.choose surrogate } \\
\text { 2. clarify patient } \\
\text { values over time } \\
\text { 3. establish leeway } \\
\text { in surrogate } \\
\text { decision making }\end{array}$ & $\begin{array}{l}\text { Strong: } \\
\text { Recommendation } \\
\text { that focus should } \\
\text { be preparation of } \\
\text { patient \& surrogate } \\
\text { to make best "in } \\
\text { the moment" } \\
\text { medical decisions. } \\
\text { This moves focus } \\
\text { away from making } \\
\text { premature } \\
\text { decisions w/ } \\
\text { incomplete info }\end{array}$ \\
\hline $\begin{array}{l}\text { Mallery, L, } \\
\text { Hubbard, } \\
\text { RE, } \\
\text { Moorhouse, } \\
\text { P, Koller, } \\
\text { K, \& Eeles, } \\
\text { EMP } \\
\text { (2011) J of } \\
\text { Palliative } \\
\end{array}$ & $\begin{array}{l}\text { Grounded } \\
\text { theory }\end{array}$ & $\begin{array}{l}\text { Level VI } \\
\text { Qualitative }\end{array}$ & $\begin{array}{l}\text { Semi-structured } \\
\text { interviews } \\
\mathrm{N}=28 \text { physicians } \\
20 \text { male / } 8 \text { female }\end{array}$ & $\begin{array}{l}\text { Content \& } \\
\text { structure of } \\
\text { CPR } \\
\text { discussion in } \\
\text { dementia case } \\
\text { study from } \\
\text { physician to } \\
\text { patient / } \\
\text { family } \\
\end{array}$ & $\begin{array}{l}\text { 86\% didn’t discuss } \\
\text { capacity; } 82 \% \text { didn’t } \\
\text { ask about adv dir; } 75 \% \\
\text { didn’t explain CPR w/ } \\
\text { illness burden; 68\% } \\
\text { didn’t explain purpose } \\
\text { of conversation; 79\% } \\
\text { didn't check } \\
\text { understanding } \\
\end{array}$ & $\begin{array}{l}\text { Taped } \\
\text { interviews; } \\
3 \\
\text { analyzers } \\
\text { w/ } \\
\text { discussion } \\
\& \\
\text { agreement }\end{array}$ & & moderate \\
\hline
\end{tabular}




\section{CPR Decisions in Nursing Home Residents}

M. Bennett DNP Candidate

\begin{tabular}{|c|c|c|c|c|c|c|c|c|}
\hline \multicolumn{9}{|l|}{ Care, 27(1) } \\
\hline $\begin{array}{l}\text { First } \\
\text { Author } \\
\text { (year) }\end{array}$ & $\begin{array}{l}\text { Conceptual } \\
\text { Framework }\end{array}$ & Design/Method & Sample/Setting & $\begin{array}{l}\text { Major } \\
\text { Variables } \\
\text { Studied } \\
\text { (and Their } \\
\text { Definitions) }\end{array}$ & Measurement & $\begin{array}{l}\text { Data } \\
\text { Analysis }\end{array}$ & Findings & $\begin{array}{l}\text { Appraisal: } \\
\text { Worth to } \\
\text { Practice }\end{array}$ \\
\hline $\begin{array}{l}\text { Barnes, K, } \\
\text { Jones, L, } \\
\text { Tookman, A } \\
\text { \& King, M } \\
\text { (2007) }\end{array}$ & N/A & $\begin{array}{l}\text { Level VI } \\
\text { Phase } 1 \text { Qualitative } \\
\text { study } \\
\text { Focus group study }\end{array}$ & $\begin{array}{l}\text { UK } \\
\text { Purposive sampling } \\
\text { for balanced sample } \\
\text { of palliative \& } \\
\text { oncology patients } \\
37 \text { approached w/ } \\
59 \% \text { agreeing to } \\
\text { participate } \\
\mathrm{N}=22 \\
8 \text { focus groups } \\
\text { approximately } 1 \mathrm{hr} \\
\text { each }\end{array}$ & $\begin{array}{l}\text { Adv Dir } \\
\text { discussions \& } \\
\text { schedule }\end{array}$ & $\begin{array}{l}\text { Explore acceptable } \\
\text { interview schedule } \\
\text { Suitability of EOL } \\
\text { discussions, timing, nature } \\
\& \text { impact }\end{array}$ & $\begin{array}{l}\text { Thematic } \\
\text { analysis }\end{array}$ & $\begin{array}{l}\text { Advance decisions } \\
\text { should not be focus } \\
\text { but broader EOL } \\
\text { issues } \\
\text { Advance Care } \\
\text { Planning (ACP) } \\
\text { should be } \\
\text { accomplished over } \\
\text { several meetings } \\
\text { HCP must be skilled } \\
\text { in reading cues, } \\
\text { responding to } \\
\text { questions, provide } \\
\text { sufficient time for } \\
\text { discussions; avoid } \\
\text { dwelling too much on } \\
\text { EOL, avoid } \\
\text { destroying hope }\end{array}$ & $\begin{array}{l}\text { Weak_-population } \\
\text { not really } \\
\text { comparable and } \\
\text { very small sample } \\
\text { Bias in sample due } \\
\text { to selection from } \\
\text { palliative \& } \\
\text { oncology patients }\end{array}$ \\
\hline
\end{tabular}


CPR Decisions in Nursing Home Residents

\section{Bennett DNP Candidate}

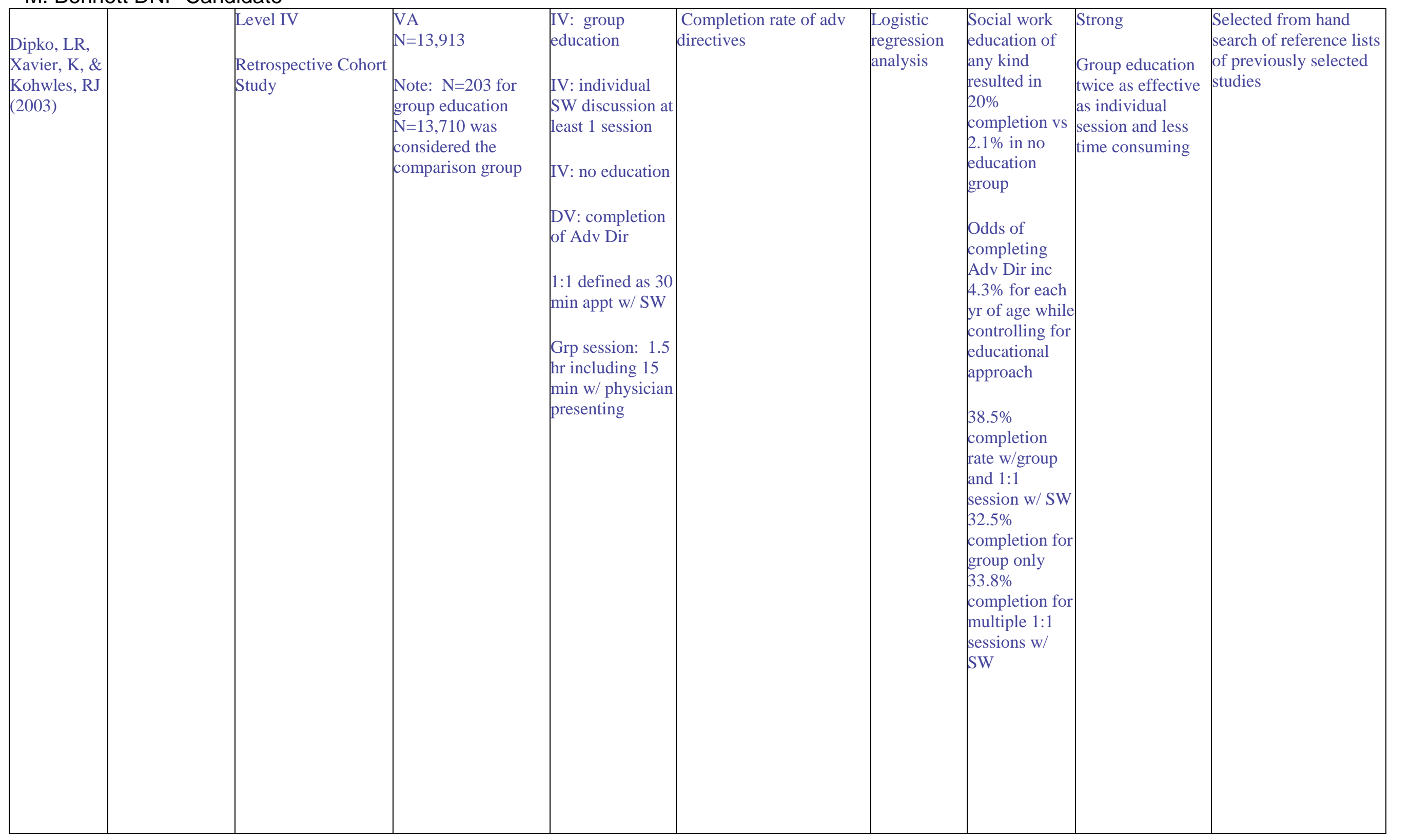

$-76-$ 
CPR Decisions in Nursing Home Residents

$-77-$

M. Bennett DNP Candidate

\begin{tabular}{|c|c|c|c|c|c|c|c|c|c|}
\hline $\begin{array}{l}\text { Volandes, A } \\
\text { E, Levin, } \\
\text { Slavin, } \\
\text { Carvajal, } \\
\text { D'Reilly, } \\
\text { Keohan, } \\
\text { Theoduolou } \\
\text {, Dickler, } \\
\text { Gerecitano, } \\
\text { et al } \\
(2011)\end{array}$ & $\mathrm{N} / \mathrm{A}$ & $\begin{array}{l}\text { Level II } \\
\text { Controlled trial w/o } \\
\text { randomization } \\
\text { Pre / post survey } \\
\text { design }\end{array}$ & $\begin{array}{l}\mathrm{N}=80 \\
\text { Inclusion / } \\
\text { exclusion criteria } \\
\text { defined for } \\
\text { population } \\
\text { poor prognosis } \\
\text { cancer returning to } \\
\text { oncologist } \\
\text { English speaking }\end{array}$ & $\begin{array}{l}\text { IV=video } \\
\text { decision aid } \\
\text { DV= preference } \\
\text { for life- } \\
\text { prolonging; } \\
\text { basic or } \\
\text { comfort care- } \\
\text { change from } \\
\text { pre video to } \\
\text { post video }\end{array}$ & $\begin{array}{l}\text { Preferred goals of care: } \\
\text { Life prolonging=vent / } \\
\text { CPR } \\
\text { Limited / basic } \\
\text { care=hospital / ATB but } \\
\text { no CPR } \\
\text { Comfort care=symptom } \\
\text { relief } \\
\text { Evaluated goals of care } \\
\text { pre and post video } \\
\text { decision aid }\end{array}$ & $\begin{array}{l}\text { Significanc } \\
\text { e } p<.05\end{array}$ & $\begin{array}{l}\text { Not significant for } \\
\text { change in goals of } \\
\text { care } \\
\text { was significant for } \\
\text { decision for no CPR } \\
\text { from } 71 \% \text { to } 62 \% \\
\text { post video }(p=.03) \\
\text { and no vent } 80 \% \text { to } \\
67 \% \text { post video } \\
(p=.008) \\
\text { Documented code } \\
\text { status in chart not } \\
\text { reflective of } \\
\text { decision-only } 5 \% \\
\text { reflected wishes } \\
\text { with } \mathrm{Cl}-.06 \text { - .04 }\end{array}$ & $\begin{array}{l}\text { Very strong worth } \\
\text { to practice } \\
\text { participants } \\
\text { recognized } \\
\text { resusciation } \\
\text { impacted by dx } \\
\text { and not as } \\
\text { effective }\end{array}$ & \\
\hline $\begin{array}{l}\text { "New } \\
\text { hospice } \\
\text { facts and } \\
\text { figures," } \\
\text { Medical } \\
\text { Ethics } \\
\text { Advisor, } \\
\text { March } \\
2012, \text { p. } \\
31 .) \\
\text { California } \\
\text { HealthCare } \\
\text { Foundation }\end{array}$ & $N / A$ & Survey & No details given & $\begin{array}{l}\text { Opinion } \\
\text { EOL wishes } \\
\text { knowledge } \\
\text { communication } \\
\text { of wishes }\end{array}$ & $\begin{array}{l}\text { Presence / absence } \\
\text { survey details not } \\
\text { provided }\end{array}$ & Percentage & $\begin{array}{l}80 \% \text { respondants } \\
\text { thought important to } \\
\text { put EOL wishes in } \\
\text { writing } \\
<\text { than } 25 \% \text { had } \\
\text { actually put their } \\
\text { wishes in writing } \\
40 \% \text { had discussed } \\
\text { w/ loved one } \\
75 \% \text { had heard of } \\
\text { hospice } \\
<40 \% \text { heard of adv } \\
\text { directives } \\
\text { "too many other } \\
\text { things to worry } \\
\text { about" was top } \\
\text { reason for not } \\
\text { discussing w/ loved } \\
\text { one }\end{array}$ & $\begin{array}{l}\text { Moderate worth- } \\
\text { survey population } \\
\text { unknown / survey } \\
\text { questions not } \\
\text { detailed }\end{array}$ & \\
\hline
\end{tabular}


CPR Decisions in Nursing Home Residents

\section{Bennett DNP Candidate}

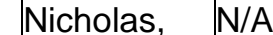

Nicholas, N/A

Langa,

Iwashyna \&

Weir

(Oct 5,

2011)

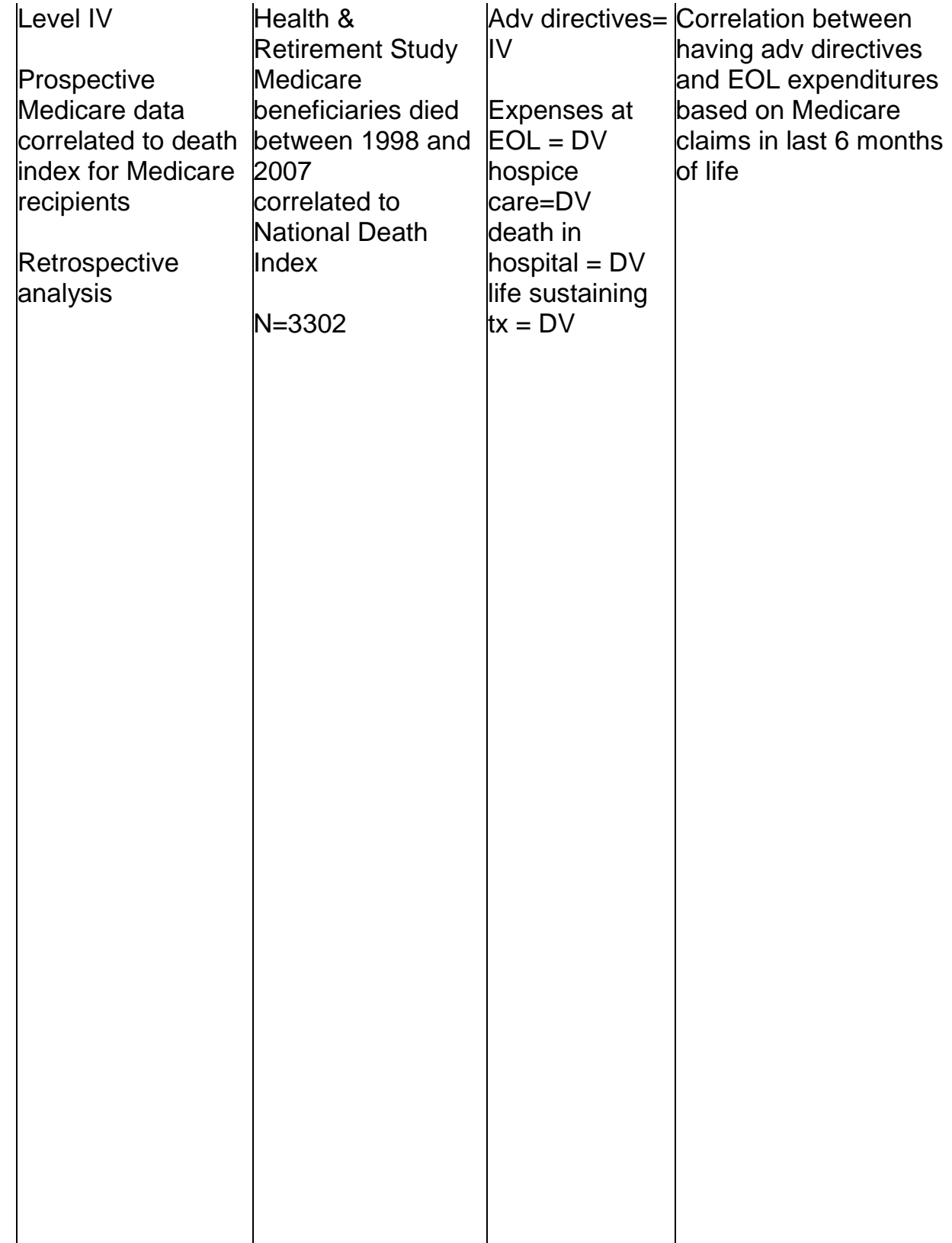

Regions High spending

specified by regions-Adv dir

high, limiting tx impacted

medium EOL Medicare

and low expenses: dec

EOL

$\$ 5585 ; 95 \% \mathrm{Cl}(-$

inhospital \$10903 to $-\$ 267$ )

expenses in

last 6

Not sig impact in

months life med/low expense regions;

Multivariab

regression

Directives were

associated with lowe adjusted probabilities

n-hospital death in high- and mediumspending regions

$(-9.8 \% ; 95 \% \mathrm{Cl}$,

$-16 \%$

to $-3 \%$ in high-

spending regions;

$-5.3 \%$; $95 \% \mathrm{Cl},-10 \%$ to $-0.4 \%$ in medium spending

regions)

Advance directives were associated with

higher adjusted

probabilities

of hospice use in high-

and medium-spending regions (17\%; $95 \% \mathrm{Cl}$

$11 \%$

to $23 \%$ in high-

spending regions

$11 \% ; 95 \% \mathrm{Cl}, 6 \%$ to

$16 \%$ in medium-

spending

regions), but not in

ow-spending regions

Strong worth to practice:

EOL Medicare

expenditures use

public tax dollars

Opportunity to

reduce spending

and improve

quality of life so pt

wishes match care

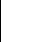


CPR Decisions in Nursing Home Residents

\section{Bennett DNP Candidate}

\begin{tabular}{|c|c|c|c|c|c|c|c|c|c|}
\hline $\begin{array}{l}\text { Levi, } \\
\text { Heverley \& } \\
\text { Green } \\
\text { (Fall 2011) }\end{array}$ & $\mathrm{N} / \mathrm{A}$ & $\begin{array}{l}\text { Level III } \\
\text { Controlled trial w/o } \\
\text { randomization of } \\
\text { patients / docs } \\
\text { randomized }\end{array}$ & $\begin{array}{l}\mathrm{N}=19 \text { patients } \\
\mathrm{N}=14 \text { physicians } \\
\text { interactive, } \\
\text { computer } \\
\text { generated adv dir } \\
\text { increase } \\
\text { agreement } \\
\text { between doc \& } \\
\text { patient wishes }\end{array}$ & $\begin{array}{l}\text { IV=computer } \\
\text { interactive } \\
\text { decision aid } \\
\text { DV=pt / doc } \\
\text { agreement } \\
\text { based on } \\
\text { computer } \\
\text { generated adv } \\
\text { dir }\end{array}$ & $\begin{array}{l}3 \text { physicians made tx } \\
\text { decisions based on adv } \\
\text { dir in } 6 \text { scenarios } \\
\text { Pt reviewed doc tx } \\
\text { decision to evaluate if it } \\
\text { matched their wishes }\end{array}$ & $\begin{array}{l}\text { Percentage } \\
\text { agreement; } \\
10 \text { point } \\
\text { scale on } \\
\text { agreement }\end{array}$ & $\begin{array}{l}84 \% \\
\text { agreement } \\
\text { between doc } \\
\& \text { pt for all tx } \\
\text { decisions } \\
82 \% \\
\text { agreement } \\
\text { on use of } \\
\text { vent as tx } \\
75 \% \\
\text { agreement } \\
\text { on use of } \\
\text { CPR as tx } \\
\text { Pt evaluation } \\
\text { of doc ability } \\
\text { to support } \\
\text { their wishes } \\
8.4 \text { on } 1-10 \\
\text { scale with } \\
\text { range } 6.5- \\
10 \\
\text { Doc } \\
\text { evaluationof } \\
\text { ability to } \\
\text { accurately } \\
\text { reflect pt } \\
\text { wishes } 7.8 \\
\text { on } 1-10 \text { scale } \\
\text { with range } \\
6.1 \text { to } 9.3\end{array}$ & $\begin{array}{l}\text { Moderate worth } \\
\text { to practice } \\
\text { sample size } \\
\text { small } \\
\text { no power } \\
\text { analysis } \\
\end{array}$ & $\begin{array}{l}\text { F/U "Making Your } \\
\text { Wishes Known: } \\
\text { Planning Your } \\
\text { Medical Future." }\end{array}$ \\
\hline
\end{tabular}

$-79-$ 
CPR Decisions in Nursing Home Residents

\section{Bennett DNP Candidate}

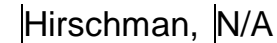

Hirschman, $\mid$ N/A

Abbott,

Hanlon,

Bettger \&

Naylor

$(2012)$
Level IV

Cross sectional study
$N=470$

$\mathrm{AL}=153$

$\mathrm{NH}=145$

Comm $=144$

Philadelphia or NY livingn will /

DHCPOA

spoke English /

Spanish

exclude MMSE <12

exclude prior use of

comm services /

LTSS

Include initial use of long term support services $<6$ months

LTSS
$-80-$

IV=initial use of Interview questions:

$\mathrm{DV}=$ presence Multivariate living will / practice-timing Presence adv dir / living logistic

adv dir /

DHCPOA

adv directives will / DHCPOA regression

sig health changes $<6$ months

(living will: $X^{2}$ :

120.9; $\mathrm{P}<$

.001 ; health

care power of

attorney: $X^{2}$

$69.1 ; \mathrm{P}<$

.001). In

multivariate

logistic

regression

models,

receiving

LTSS at an

ALF (OR $1 / 4$

5.01; $\mathrm{P}<$

$.001)$, being

white (OR $1 / 4$

2.87; $\mathrm{P}<$

.001), having

more

than 12 years

of education

(OR 1/4 2.50;

$P<.001)$,

and

experiencing

a significant

health

change in

past 6

months (OR

$1 / 4$ 1.97; P

$1 / 4.007)$ were

predictive of

having a

living will.

Receiving discussion 
CPR Decisions in Nursing Home Residents

M. Bennett DNP Candidate
$-81-$

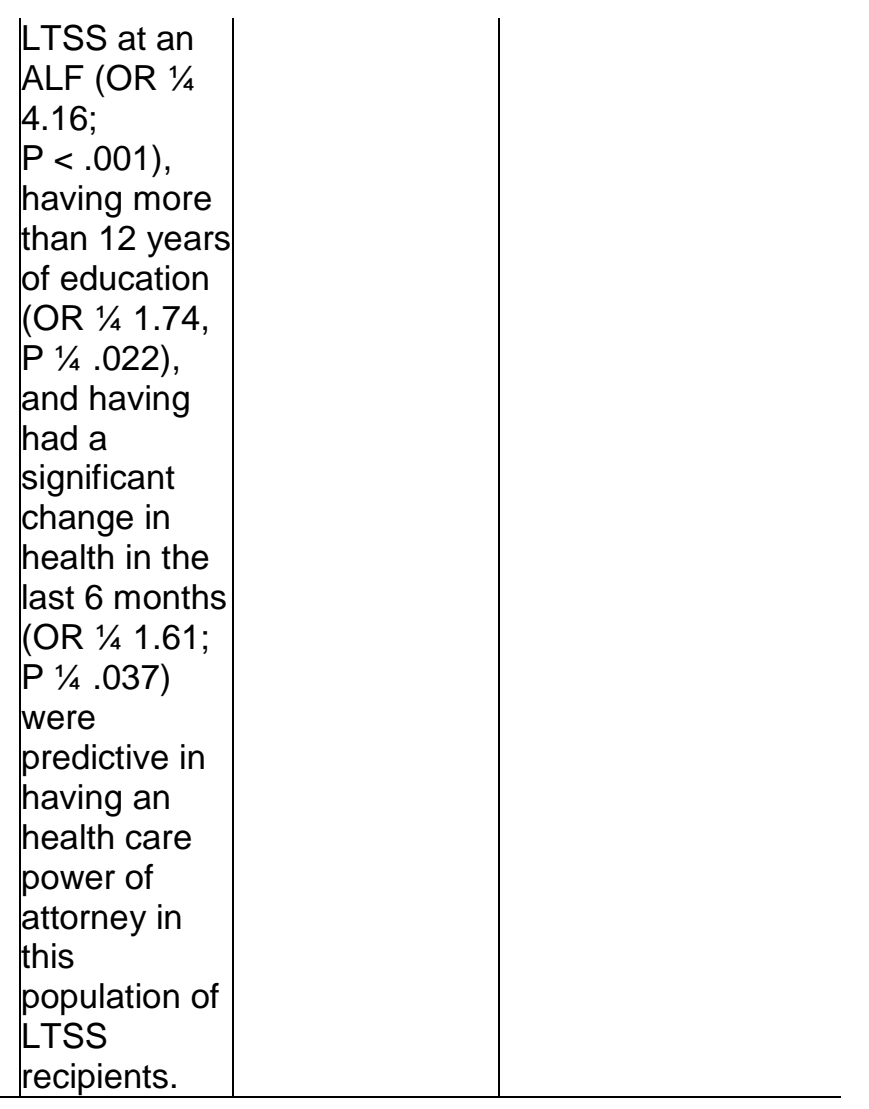




\section{Appendix G: CPR Video Decision Tool EBP Implementation Plan}

\begin{tabular}{|l|l|}
\hline PICOT Question & $\begin{array}{l}\text { Do nursing home residents and their decision makers who use } \\
\text { a CPR video decision tool, choose CPR less frequently than } \\
\text { nursing home residents and their decision makers who do not } \\
\text { use a CPR video decision tool over a three month time period? }\end{array}$ \\
\hline Team Members & $\begin{array}{l}\text { Dr. Todd Sobol, Suzanne Fischer, Judi Segbefia, Sharon } \\
\text { Phillips, Ginger Bryant, NPs and DNP student }\end{array}$ \\
\hline EBP Mentor \& Contact Info & Dr. Gail Moddeman (937) 545-5140 cell \\
\hline
\end{tabular}

\begin{tabular}{|c|c|c|}
\hline Preliminary Checkpoint & $\begin{array}{l}\text { Who are stakeholders? } \\
\text { Active \& Supportive? } \\
\text { Project team leadership \& roles } \\
\text { Acquisition of necessary } \\
\text { approvals for project } \\
\text { implementation } \\
\text { Begin relationship with EBP } \\
\text { Mentor }\end{array}$ & $\begin{array}{l}\text { Identified \& on board } \\
\text { Identified \& on board } \\
\text { In process-expedited IRB } \\
\text { approval and proposal defense } \\
\text { needed yet }\end{array}$ \\
\hline Checkpoint One & $\begin{array}{l}\text { Hone PICOT question \& assure } \\
\text { team is prepared } \\
\text { Build EBP knowledge \& skills } \\
\text { Begin relationship with EBP } \\
\text { Mentor }\end{array}$ & $\begin{array}{l}\text { Completed } \\
\text { Skills in EBP continually } \\
\text { improving } \\
\text { Relationship established and } \\
\text { committee assembled }\end{array}$ \\
\hline Checkpoint Two & $\begin{array}{l}\text { Conduct literature search \& retain } \\
\text { studies that meet inclusion criteria } \\
\text { Connect with librarian } \\
\text { TEAM BUILD with implementation } \\
\text { group } \\
\text { Begin relationship with EBP } \\
\text { Mentor }\end{array}$ & $\begin{array}{l}\text { Completed and updated } \\
16 \text { studies included } \\
\text { March 2011-librarian } \\
\text { Ongoing team building and } \\
\text { stakeholder communication } \\
\text { Relationship continues to } \\
\text { deepen }\end{array}$ \\
\hline Checkpoint Three & $\begin{array}{l}\text { Critically appraise literature } \\
\text { Meet with group to discuss how } \\
\text { evidence answers question; pose } \\
\text { follow up questions; re-review } \\
\text { literature as necessary } \\
\text { Begin relationship with EBP } \\
\text { Mentor }\end{array}$ & $\begin{array}{l}\text { Literature review updated } \\
\text { CPR video tool demonstrated to } \\
\text { leadership team } \\
\text { Continue to massage } \\
\text { stakeholders }\end{array}$ \\
\hline Checkpoint Four & $\begin{array}{l}\text { Meet with group } \\
\text { Summarize evidence with focus } \\
\text { on implications for practice \& } \\
\text { conduct interviews with content } \\
\text { experts as necessary to } \\
\text { benchmark } \\
\text { Begin relationship with EBP } \\
\text { Mentor }\end{array}$ & $\begin{array}{l}\text { Met with leadership team and } \\
\text { medical director } \\
\text { CPR \% established for all } \\
\text { facilities as baseline } \\
\text { Six identified for initial } \\
\text { implementation and } \\
\text { corresponding NPs } \\
\text { Continue to build relationship } \\
\text { with Project Chair }\end{array}$ \\
\hline Checkpoint Five & $\begin{array}{l}\text { Define project purpose-connect } \\
\text { the evidence with the project } \\
\text { Define baseline data collection } \\
\text { sources (e.g. dataset, EHR, } \\
\text { methods \& measures) }\end{array}$ & $\begin{array}{l}\text { Project clarified to NP } \\
\text { intervention vs group } \\
\text { intervention } \\
\text { Outcome measures established } \\
\text { and baseline obtained for }\end{array}$ \\
\hline
\end{tabular}




\begin{tabular}{|c|c|c|}
\hline & $\begin{array}{l}\text { Begin relationship with EBP } \\
\text { Mentor }\end{array}$ & $\begin{array}{l}\text { comparison } \\
\text { Continue to build relationship } \\
\text { with Project Chair }\end{array}$ \\
\hline Checkpoint Six & $\begin{array}{l}\text { Meet with implementation group } \\
\text { Discuss known barriers \& } \\
\text { facilitators of project } \\
\text { Discuss strategies for minimizing } \\
\text { barriers \& maximizing facilitators } \\
\text { Finalize protocol for } \\
\text { implementation of evidence } \\
\text { Identify resources (human, fiscal } \\
\text { \& other) necessary to complete } \\
\text { project } \\
\text { Supply EBP Mentor with written } \\
\text { IRB approval \& managerial } \\
\text { support } \\
\text { Begin work on poster for } \\
\text { dissemination of initiation of } \\
\text { project \& progress to date to } \\
\text { educate stakeholders about } \\
\text { project } \\
\text { Include specific plan for how } \\
\text { evaluation will take place: who, } \\
\text { what, where, when \& how, and } \\
\text { communication mechanisms with } \\
\text { stakeholders } \\
\text { Begin relationship with EBP } \\
\text { Mentor }\end{array}$ & $\begin{array}{l}\text { Met with leadership team in } \\
\text { October } 2011 \text { to review project } \\
\text { Resources identified } \\
\text { Met with Dr. Volandes and } \\
\text { negotiated fees } \\
\text { Invoices submitted for payment } \\
\text { Continue to work with Project } \\
\text { Chair for expedited IRB } \\
\text { approval and project proposal } \\
\text { defense. } \\
\text { Application submitted for May } \\
2012 \text { Ohio Health Care } \\
\text { Association conference as } \\
\text { presenter to begin to } \\
\text { disseminate findings to long } \\
\text { term care industry } \\
\text { Evaluation of outcomes is } \\
\text { through CIS report which is } \\
\text { pulled from EHR quarterly and } \\
\% \text { residents requesting CPR is } \\
\text { one metric identified only by } \\
\text { facility not by resident name }\end{array}$ \\
\hline Checkpoint Seven & $\begin{array}{l}\text { Meet with implementation group to } \\
\text { review proposed poster } \\
\text { Make final adjustment to poster } \\
\text { with support staff } \\
\text { Inform stakeholders of start date } \\
\text { of implementation \& poster } \\
\text { presentation } \\
\text { Address nay concerns or } \\
\text { questions of stakeholders } \\
\text { Begin relationship with EBP } \\
\text { Mentor }\end{array}$ & \\
\hline Checkpoint Eight & $\begin{array}{l}\text { Poster presentation (preferred } \\
\text { event is a system-wide recognition } \\
\text { of quality, research or innovation) } \\
\text { LAUNCH EBP implementation } \\
\text { project } \\
\text { Begin relationship with EBP } \\
\text { Mentor }\end{array}$ & \\
\hline Checkpoint Nine & $\begin{array}{l}\text { Mid-project meet with all key } \\
\text { stake-holders to review progress } \\
\text { \& provide outcomes to date } \\
\text { Review issues, successes, aha's } \\
\text { \& triumphs of project to date } \\
\text { Begin relationship with EBP } \\
\text { Mentor }\end{array}$ & \\
\hline Checkpoint Ten & Complete final data collection for & \\
\hline
\end{tabular}


M. Bennett DNP Candidate

\begin{tabular}{|l|l|l|}
\hline & project evaluation & \\
& Present project results via poster & \\
& presentation-locally \& nationally & \\
& Celebrate with EBP Mentor \& & \\
& Agency Leadership & \\
\hline Checkpoint Eleven & Review project progress, lesson & \\
& learned, new questions generated & \\
& from process & \\
& Consult with EBP Mentor about & \\
& new questions & \\
\hline
\end{tabular}

Tool from Melnyk \& Fineout-Overholt, 2011—permission granted for student use per Appendix M, p 557. 


\section{Appendix H: Sample Clinical Indicator Report}

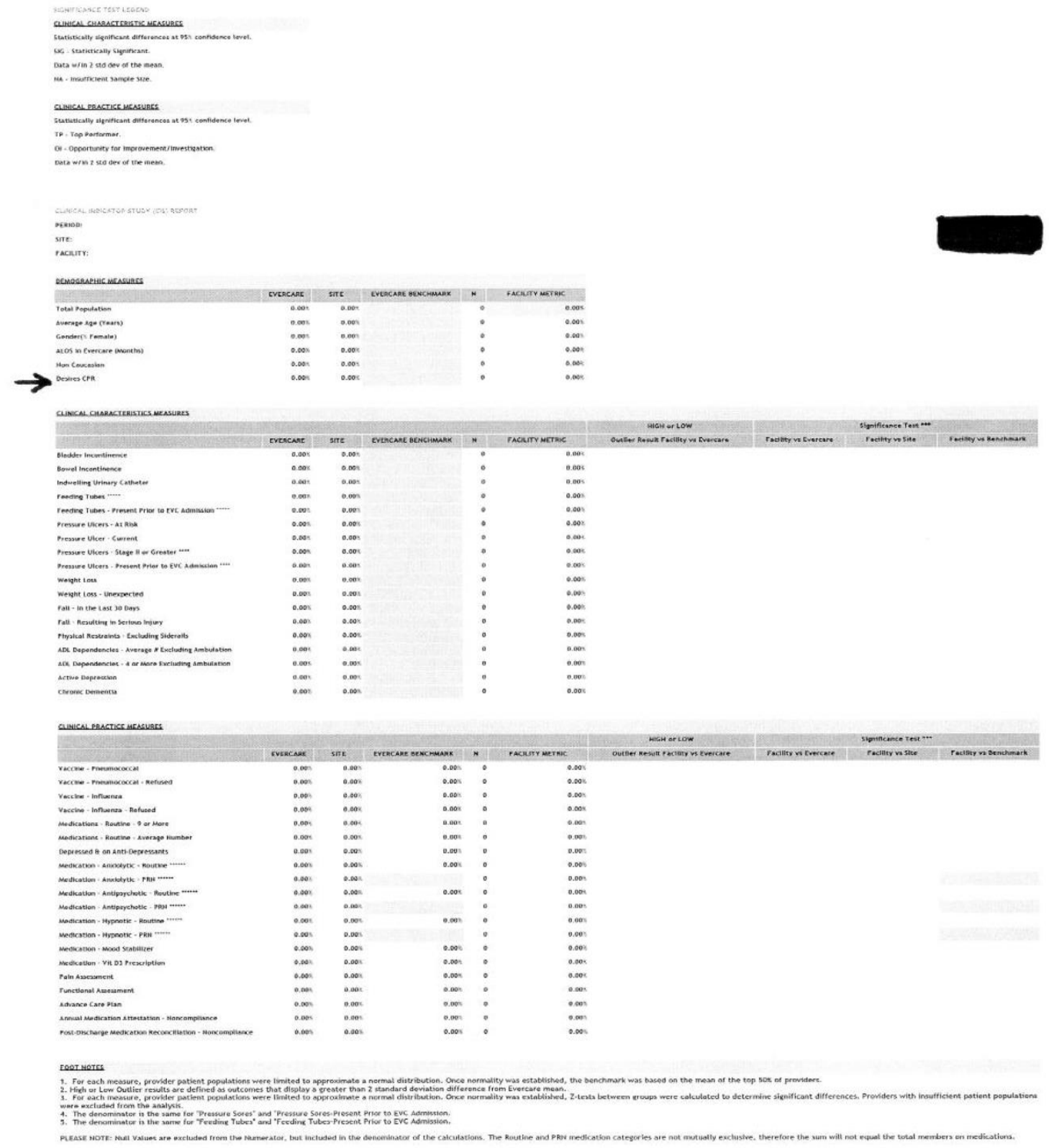




\section{Appendix I-NP Implementation Survey \\ CPR Video Pilot}

Scale

1-strongly disagree 2-disagree 3 -acceptable 4 -agree 5 -strongly agree

1. Did you feel the initial preparation and education was sufficient to implement the CPR video decision tool?

Range 3-4; Mean 3.375

2. Did you feel you were able to integrate the CPR video decision tool into advance care planning discussions?

Range 1-2; Mean 1.25

3. Recommendations to improve use of the CPR video decision tool:

Implement at or prior to admission when family present-3 comments Try using at a family night group presentation-2 comments

4. Recommendations to improve initial preparation and education process:

Do presentation to nursing home DON \& LSW

Do presentation to MDS nurse and other nursing leadership

5. Detail challenges you identified in integrating the CPR video decision tool:

Lack of family involvement-4 comments

Unable to get family to call back or respond-4 comments

Lots of technological challenges-6 comments

Seemed too late - need to use before admission to nursing home 
M. Bennett DNP Candidate

\section{Appendix J-Post Implementation Call Log}

\begin{tabular}{|c|c|c|c|}
\hline Date & Concern & Action Plan & Comments \\
\hline $\operatorname{Jan} 3,2012$ & $\begin{array}{l}\text { Unable to get video to load on } \\
\text { laptop }\end{array}$ & $\begin{array}{l}\text { Work with } \\
\text { Jason in IT }\end{array}$ & $\begin{array}{l}\text { New software } \\
\text { pushed to all } \\
\text { NPs' laptops }\end{array}$ \\
\hline $\begin{array}{l}79 \% \\
\text { participation }\end{array}$ & & $\begin{array}{l}\text { Obtain file in } \\
\text { different } \\
\text { software from } \\
\text { Dr. Volandes }\end{array}$ & \\
\hline & & $\begin{array}{l}\text { Jason to } \\
\text { download video } \\
\text { files to } \\
\text { sharepoint site }\end{array}$ & \\
\hline Jan 10, 2012 & $\begin{array}{l}\text { Everyone verified access to video } \\
\text { on laptop and sharepoint }\end{array}$ & & \\
\hline $\begin{array}{l}79 \% \\
\text { participation }\end{array}$ & $\begin{array}{l}\text { Request for hard copy DVDs to } \\
\text { share with family members }\end{array}$ & $\begin{array}{l}\text { Gina to burn } \\
\text { DVDs and send } \\
\text { to families at } \\
\text { NP request }\end{array}$ & $\begin{array}{l}\text { Software } \\
\text { requested \& } \\
\text { installed on } \\
\text { Gina's computer } \\
\text { to burn DVDs }\end{array}$ \\
\hline Jan 17, 2012 & $\begin{array}{l}\text { Families / residents state it's } \\
\text { "God's will" and will die despite } \\
\text { CPR }\end{array}$ & $\begin{array}{l}\text { Mirror terms } \\
\text { used by pt/ } \\
\text { family; } \\
\text { emphasize } \\
\text { control of } \\
\text { destiny; decide } \\
\text { for self in } \\
\text { advance; } \\
\text { Support } \\
\text { spiritual piece } \\
\text { for pt / family }\end{array}$ & \\
\hline \multicolumn{4}{|l|}{$\begin{array}{l}65 \% \\
\text { participation }\end{array}$} \\
\hline Jan 24, 2012 & $\begin{array}{l}\text { Shared with nursing leadership } \\
\text { and had positive comments }\end{array}$ & $\begin{array}{l}\text { Add to list of } \\
\text { improvements } \\
\text { for next rollout }\end{array}$ & \\
\hline \multicolumn{4}{|l|}{$\begin{array}{l}79 \% \\
\text { participation }\end{array}$} \\
\hline Feb 28, 2012 & $\begin{array}{l}\text { When can use be expanded } \\
\text { beyond pilot facilities? }\end{array}$ & $\begin{array}{l}4 / 1 / 12 \text { is plan to } \\
\text { implement } \\
\text { across site }\end{array}$ & \\
\hline $\begin{array}{l}50 \% \\
\text { participation }\end{array}$ & & & \\
\hline
\end{tabular}

